Nakhoda: Jurnal Ilmu Pemerintahan

Vol. 19 No. 2 Tahun 2020 Halaman 128-150

e-ISSN: 2656-5277 | p-ISSN: 1829-5827

\title{
Problematika Kewenangan Administrasi Kependudukan Sesuai Peraturan Pemerintah Nomor 40 Tahun 2019
}

\author{
The Problems of Population Administration Authority \\ Accordance of Government Regulation Number 40 of 2019
}

\author{
Ashara Putra Mansien
}

Analis Kebijakan Pemerintah Provinsi Kalimantan Tengah, Palangka Raya, Indonesia

asharamansien@gmail.com

Diterima: 18 Oktober 2020

Direvisi: 29 Desember 2020

Disetujui: 30 Desember 2020

DOI: 10.35967/njip.v19i2.109

\begin{abstract}
Abstrak: Kajian ini berupaya untuk memahami kendala-kendala eksternal yang muncul dalam pelaksanaan kewenangan administrasi kependudukan yang bersumber dari ketatnya regulasi kementerian terhadap daerah dan pembagian kewenangan antara pemerintah pusat dan daerah. Tulisan ini bertujuan untuk menganalisis potensi hambatan penyelenggaraan urusan administrasi kependudukan sesuai PP No. 40/2019. Metode penelitian menggunakan studi pustaka, di mana penulis mengumpulkan data-data secara sistematis dan membuat sintesisnya. Pertama ditemukan hambatan distorsi dalam pelaksanaan asas penyelenggaraan pemerintahan daerah di mana terjadi benturan regulasi antara pusat dan daerah, pengaturan pusat cenderung sentralistis dan hal ini berpengaruh pada komposisi anggaran yang tidak berimbang menyebabkan daerah kesulitan untuk bekerja secara maksimal. Kedua, distribusi urusan administrasi kependudukan dan kriteria pembagian urusan. Di mana kementerian memberikan perintah yang tidak tertulis dalam PP 40/2019 serta mengerjakan urusan yang telah dikerjakan di daerah. Lalu pendistribusian fungsi pengawasan dan koordinasi yang lemah dalam pelaksanaan kegiatan menyebabkan konflik antara provinsi dan kabupaten/kota. Kesimpulannya pelaksanaan PP No. 40 Tahun 2019 menimbulkan hambatan dalam hubungan kewenangan, kelembagaan, keuangan, dan pengawasan antara pemerintah pusat dan daerah. Solusi yang ditawarkan yakni memperbaiki pola komunikasi dan koordinasi dan pemerintah pusat segera membentuk kantor perwakilan di provinsi, kabupaten/kota dan desa yang khusus mengerjakan kewenangan dekonsentrasi/tugas pembantuan.
\end{abstract}

Kata Kunci: Sentralisasi, Administrasi kependudukan, Kewenangan

\begin{abstract}
This study seeks to understand the external constraints that arise in the implementation of population administration authority that stems from the tightness of ministerial regulations on regions and the division of authority between the central and regional governments. This paper aims to analyze potential obstacles in the implementation of population administration affairs according to Government Regulation Number 40/2019. The research method uses a literature study, where the authors collect data systematically and make a synthesis. First, there is a distortion in the implementation of the principles of regional governance where there is a conflict between central and regional regulations, central regulations tend to be centralized and this affects the unbalanced budget composition, making it difficult for regions to work optimally. Second, the distribution of population administrative affairs and the criteria for assigning functions. Where the ministry gives orders that are not written in PP 40/2019 and work on things that have been done in the regions. Then the weak distribution of monitoring and coordination functions in the implementation of activities causes conflicts between provinces and districts/cities. In conclusion, the implementation of PP. 40 of 2019 raises obstacles in the relation of authority, institution, finance, and supervision of the central and regional governments. The solution offered is to improve communication and coordination patterns and the central government immediately to establish representative offices in provinces, districts/cities, and villages that specifically work on deconcentration/assistance tasks.
\end{abstract}

Keywords: Centralization, Population administration, Authority 
Nakhoda: Jurnal Ilmu Pemerintahan

Vol. 19 No. 2 Tahun 2020 Halaman 128-150

e-ISSN: 2656-5277 | p-ISSN: 1829-5827

\section{Pendahuluan}

Undang-Undang Nomor 25 Tahun 2009 tentang Pelayanan Publik, menjelaskan bahwa negara berkewajiban menyelenggarakan sejumlah pelayanan guna memenuhi hakhak dasar warganya mulai dari tingkat nasional hingga tingkat terbawah yaitu desa sehingga dalam konteks demokrasi, keadilan pelayanan tersebut harus dipenuhi secara komprehensif (Bansaleng, 2017). Berbagai pelayanan administratif, seperti pelayanan eKTP, akta kelahiran, sertifikasi tanah, dan perizinan, merupakan pelayanan yang diselenggarakan untuk menjamin hak dan kebutuhan dasar warga negara.

Berbagai penelitian sebelumnya menyatakan urusan administrasi kependudukan memiliki kendala di berbagai aspek. (Pratama, 2013) menyatakan kendala infrastruktur pendukung, kualitas pelayanan dan tenaga operasional. (Lubis \& Mulyaningsih, 2016; Setiawan \& Ikhsanditya, 2020) menyatakan kendala partisipasi masyarakat, infrastruktur pendukung dan kualitas pelayanan serta (Ripa'i, 2018; Sukma et al., 2018) menyatakan kendala tenaga operasional, SDM dan partisipasi masyarakat. Begitu juga kendala yang sama dihadapi daerah-daerah di Kalimantan Tengah, sehingga menurut penulis kendala utama yang terjadi lebih disebabkan kepada pola komunikasi pemerintah pusat-daerah yang kurang baik dan ketidakadilan pembagian kewenangan dari pusat.

Dalam (Strong, 2011) menyatakan konsep negara kesatuan (unitary state) adalah pemerintah pusat selaku pemegang kekuasaan tertinggi dapat menyerahkan sebagian kewenangannya kepada daerah otonom melalui desentralisasi. Mencermati (Strong, 2011), menurut kami penyelenggaraan desentralisasi di Indonesia sudah lebih baik dalam artian pembagian urusan pemerintahan tidak hanya berdasarkan prinsip "residu" tetapi justru sebaliknya (UU 23/2014 tidak memberikan kewenangan sisa). Pemerintah pusat telah melimpahkan urusan administrasi kependudukan yang sangat besar kepada pemerintah daerah untuk dikelola dan dipertanggungjawabkan, meskipun dalam pembagian itu merujuk (Fatmawati, 2018; Wicaksono, 2012) terjadi pemusatan kewenangan dan menurut (Rauf, 2018b) terjadi ketimpangan pembagian kewenangan. Dampaknya terjadi pada saat pelayanan administrasi kependudukan (terutama melalui sistem online) yakni alat rekam cetak e-KTP dan peralatan Sistem Informasi Administrasi Kependudukan (SIAK) usang, sarana dan prasarana infrastruktur pelayanan kurang memadai, SDM aparat kurang cakap, keterbatasan dana bimtek/diklat dll.

Masalah nyata kedua yang muncul dalam administrasi kependudukan oleh disdukcapil provinsi maupun kabupaten/kota ialah pusat mendistribusikan urusan yang telah dilaksanakan di daerah (Mujahidin \& Wiredarme, 2020). Sebagai contoh, urusan pelaporan data kependudukan setiap bulan telah diserahkan kepada pemerintah kabupaten/kota, namun kembali didelegasikan kepada provinsi selaku wakil pemerintah pusat untuk direkapitulasi. Padahal kementerian memiliki aplikasi yang secara otomatis menghubungkan data pelayanan administrasi kependudukan di seluruh Indonesia. Hal ini membuat disdukcapil provinsi bingung sumber data manakah yang digunakan.

Kemudian pelimpahan kewenangan yang belum diatur secara jelas antara tugas pemerintah provinsi dan kab/kota di undang-undang maupun peraturan pemerintah dalam pengawasan mengakibatkan wewenang campur tangan pemerintah provinsi terhadap urusan pengawasan administrasi kependudukan disdukcapil kabupaten/kota cukup lemah (Azhar, 2012). Padahal disdukcapil provinsi memiliki fungsi supervisi, koordinasi dan fasilitasi terhadap pemda kabupaten/kota (Rauf, 2018a). Sejatinya esensi penyelenggaraan desentralisasi dan otonomi daerah adalah terjadinya penyerahan kewenangan dari pemerintah pusat kepada pemerintah daerah (Akbal, 2016). Hal ini sejalan dengan pendapat Parson dalam (Romli, 2007) bahwa desentralisasi adalah pelimpahan tanggung jawab administratif dari pusat kepada pemerintah daerah. Selanjutnya, Smith dalam (Romli, 2007) menyebutkan desentralisasi adalah pelimpahan kekuasaan dari atasan kepada bawahan 
Nakhoda: Jurnal Ilmu Pemerintahan

Vol. 19 No. 2 Tahun 2020 Halaman 128-150

e-ISSN: 2656-5277 | p-ISSN: 1829-5827

dalam suatu hubungan hierarki, bisa berupa pemerintah pusat menyerahkan kewenangan kepada daerah atau instansi lain.

Selanjutnya (H. R. Ridwan, 2003) menyatakan kewenangan adalah kemampuan pemerintah melaksanakan tanggung jawab yang tercantum dalam perundang-undangan sehingga tercipta siklus kepatuhan antar warga negara dengan pemerintah. Sedangkan (J. Ridwan \& Sodik, 2012), mengungkapkan kewenangan atribusi merupakan kewenangan asli yang berasal dari konstitusi perundang-undangan dan hanya dimiliki oleh Presiden, DPR dan DPD. Kemudian (Thoha, 2003) menemukan bahwa sentralisasi kekuasaan menyebabkan pejabat di tingkat tinggi memiliki kekuasaan yang berlebih dan memperlemah kekuasaan pejabat yang berada di tingkat bawah, dan menjadi semakin bertolak belakang ketika harus melayani masyarakat yang berada di luar sistem hierarki.

Berangkat dari konsep hierarki dan kekuasaan tersebut, maka (Thoha, 2004) menyatakan perlu ada transfer kewenangan dari level atas ke level bawah guna menghindari penumpukan kekuasaan. Kewenangan adalah otoritas pejabat secara legal untuk bertindak dan bertanggungjawab agar institusinya dapat berjalan baik. Otoritas adalah kekuasaan pejabat dalam suatu organisasi. Pelimpahan kewenangan berarti penyerahan sebagian kewenangan dari pejabat satu ke pejabat lainnya untuk bertindak dan bertanggungjawab agar institusi dapat berjalan normal. Menurut (Sutarto, 2000), pendelegasian wewenang dapat dilakukan oleh pejabat yang berkedudukan lebih tinggi (superior) kepada pejabat yang berkedudukan rendah (subordinate) atau pejabat level atas kepada pejabat level bawah (vertikal) dan pada jenjang yang sama antara pejabat yang sederajat (horizontal).

Selanjutnya (Wasistiono, 2003) membedakan kewenangan menjadi atributif dan delegatif. Atributif artinya penyerahan kewenangan kepada institusi atau pejabat berdasarkan peraturan perundang-undangan. Sedangkan delegatif artinya penyerahan kewenangan yang berasal dari institusi atau pejabat yang lebih tinggi. Dengan dilimpahkannya wewenang maka secara otomatis pejabat akan bertanggungjawab penuh atas tugas yang telah dibebankan. Prinsip-prinsip pelimpahan kewenangan yang efektif dalam (Wasistiono, 2003), meliputi:

a) Pelimpahan dapat dilakukan untuk mencapai tujuan dan rancangan yang telah ditetapkan oleh organisasi.

b) Pelimpahan sesuai tugas atau pekerjaan yang diberikan sehingga berjalan efisien dan efektif.

c) Pelimpahan secara runtun dari hierarki jabatan level atas sampai dengan jabatan level bawah.

d) Pelimpahan kewenangan secara berjenjang dari pejabat level atas ke pejabat di bawahnya.

e) Hanya bekerja dan bertanggung jawab atasnya melalui satu perintah komando.

f) Pelimpahan kewenangan secara penuh sehingga penerima kewenangan dapat mempertanggungjawabkan pekerjaan dengan maksimal.

g) Proporsionalitas antara tanggung jawab dan kewenangan yang dimiliki.

Kemudian pelimpahan kewenangan dalam administrasi kependudukan sesuai Undang-Undang Nomor 24 Tahun 2013 Tentang Perubahan Atas Undang-Undang Nomor 23 Tahun 2006 Tentang Administrasi Kependudukan, meliputi pengelolaan kewenangan pada tahapan pendaftaran, pencatatan, pengelolaan informasi dan pendayagunaan data kependudukan secara sistematis sehingga tercipta tertib administrasi dokumen kependudukan.

(Soemartono \& Hendrastuti, 2011) mengatakan bahwa keutamaan data dan informasi hasil pencatatan peristiwa kependudukan dan peristiwa penting kependudukan 
Nakhoda: Jurnal Ilmu Pemerintahan

Vol. 19 No. 2 Tahun 2020 Halaman 128-150

e-ISSN: 2656-5277 | p-ISSN: 1829-5827

akan dimanfaatkan oleh instansi pengguna (user) untuk perencanaan pembangunan berskala lokal maupun nasional, pelayanan publik, alokasi anggaran, pembangunan demokrasi, penegakan hukum dan pencegahan kriminal. Jenis-jenis peristiwa kependudukan antara lain, perubahan status orang asing tinggal terbatas menjadi tinggal tetap, tinggal terbatas, pindah datang untuk menetap dan perubahan alamat. Sedangkan Jenis peristiwa penting antara lain, ganti nama, perubahan status kewarganegaraan, kelahiran, kematian, perkawinan, dan perceraian, termasuk pengangkatan, pengakuan, dan pengesahan anak, serta peristiwa penting lainnya yang harus dilaporkan karena membawa implikasi perubahan data identitas atau surat keterangan kependudukan. Dan (Soemarsono, 2017; Soemartono \& Hendrastuti, 2011) juga menyatakan kesadaran masyarakat Indonesia untuk memiliki bukti tertulis dokumen kependudukan sudah cukup tinggi karena masyarakat semakin menyadari arti penting dokumen negara yang memberikan pengakuan dan perlindungan hukum keperdataan atas identitas pribadi.

Pemberian kewenangan dari pemerintah pusat adalah pemberian kewenangan kepada kepala daerah dan jajarannya (administratif) serta kepada pimpinan dan anggota DPRD sebagai mitra kerja kepala daerah (politis). Selanjutnya, wewenang yang telah diserahkan tersebut, baik melalui asas dekonsentrasi maupun tugas pembantuan, menjadi tanggung jawab kepala daerah (gubernur, bupati, wali kota) untuk melaksanakan dan mempertanggung jawabkannya. Yang menarik lagi, menurut Undang-Undang Nomor 23 Tahun 2014 Tentang Pemerintahan Daerah, bahwa kewenangan pemerintah provinsi dalam bidang administrasi kependudukan hanya 1 (satu) yakni membangun profil kependudukan provinsi (lampiran UU No. 23 Tahun 2014 hal. 51). Lahirnya PP No. 40 Tahun 2019 telah membawa perubahan yang berarti dalam tatanan penyelenggaraan administrasi kependudukan yakni sebagai hierarki peraturan perundang-undangan tertinggi ke-3 setelah UUD dan UU yang berfungsi sebagai aturan pelaksanaan dari undang-undang (Albintani, 2018), sekaligus membawa berbagai kejanggalan dalam implementasinya.

Tulisan ini bertujuan untuk menghasilkan analisis terhadap problematika pelaksanaan kewenangan administrasi kependudukan sesuai PP No. 40 Tahun 2019. Analisis dilakukan berdasarkan konsep (Dwiyanto, 2011) yang mengidentifikasi setidaknya dua isu yang menjadi problematika pembagian urusan pemerintahan. Pertama, distorsi dalam pelaksanaan asas penyelenggaraan pemerintahan daerah. Kedua, perubahan distribusi urusan pemerintahan dan kriteria pembagian urusan. Adapun signifikansi bagi ilmu pengetahuan dari penelitian ini adalah memberikan kebaruan ilmu pemerintahan dan manajemen birokrasi berdasarkan konsep hambatan eksternal pelaksanaan urusan pemerintahan. Target yang diharapkan dari hasil penelitian ini adalah terpublikasikannya hasil penelitian dalam Jurnal Nakhoda yaitu jurnal yang memuat studi mengenai politik, kebijakan publik dan pemerintahan. Dari penjelasan yang dikemukakan, maka penulis akan membahas "apa saja potensi hambatan penyelenggaraan urusan administrasi kependudukan sesuai PP No. 40/2019?”.

Kajian tentang penyelenggaraan kewenangan pemerintahan secara umum sudah cukup berkembang di Indonesia, namun demikian literatur dan kajian tentang penyelenggaraan kewenangan konteks administrasi kependudukan dan pencatatan sipil tidak banyak tersedia. Berbeda dengan implementasi kewenangan bidang administrasi kependudukan dan pencatatan sipil lainnya yang mengkaji faktor-faktor pengaruh dalam organisasi pemerintah daerah kabupaten/kota yang cenderung normatif. Maka secara berbeda, perspektif ini berusaha memahami hambatan eksternal yang timbul dalam pelaksanaan kewenangan administrasi kependudukan yang bersumber dari pembagian kewenangan antara pemerintah pusat dan daerah. Hambatan eksternal antara pemerintah pusat dan pemerintah daerah khususnya pemerintah daerah provinsi sebagai perwakilan 
Nakhoda: Jurnal Ilmu Pemerintahan

Vol. 19 No. 2 Tahun 2020 Halaman 128-150

e-ISSN: 2656-5277 | p-ISSN: 1829-5827

pemerintah pusat didaerah meliputi hubungan kewenangan, kelembagaan, keuangan, dan pengawasan sebagai realitas yang tidak terelakkan sehingga harus diteliti.

Penelitian yang relevan pernah dilakukan berupa disertasi terkait hambatan penyelenggaraan pelayanan administrasi kependudukan oleh Lis Febrianda tahun 2009. Hasil penelitian berupa kualitas penyelenggaraan pelayanan belum sesuai dengan prinsipprinsip hukum pelayanan publik di mana dalam menghadapi permasalahan, ASN masih menggunakan pendekatan legalistik-positivistik sehingga tidak mampu mengambil tindakan diskresi. Peran birokrasi pemerintah untuk peningkatan kualitas pelayanan melalui strategi kebijakan dan penerapan sistem informasi administrasi kependudukan. Kemudian rekonstruksi regulasi dalam pelayanan kependudukan dan pencatatan sipil dilakukan melalui normatifisasi asas-asas umum pemerintahan yang layak ke dalam UU No.23/2006. Kekurangan dari penelitian ini meskipun sudah dilakukan analisis permasalahan pelayanan kependudukan dan pencatatan sipil namun hanya fokus pada perspektif hukum dan pelayanan di kabupaten/kota, belum menyentuh konflik kewenangan yang disebabkan pembagian urusan antara pemerintah pusat dan pemerintah provinsi.

Suatu kajian yang dilakukan oleh Abdul Halik tahun 2015 menyangkut implementasi kebijakan dekonsentrasi di Provinsi Jawa Barat di mana secara normatif implementasi tersebut relatif sesuai dengan target anggaran yang telah ditetapkan. Saran penelitian ini diperlukan penguatan (reposisi atau optimalisasi) peran gubernur dalam hubungan pusat-daerah, peningkatan sinergitas pusat dan daerah dalam perencanaan dan penganggaran kegiatan dekonsentrasi, peningkatan kapasitas kelembagaan/SKPD pelaksana dekonsentrasi serta pengembangan kapasitas SDM aparatur pemerintah daerah. Kekurangan dari penelitian ini hanya menganalisis faktor yang mempengaruhi implementasi dekonsentrasi berdasarkan faktor komunikasi, sumber daya, disposisi dan struktur birokrasi pelaksanaan (teori implementasi Edward III) yang berasal dari internal organisasi birokrasi tidak menganalisis hambatan eksternal yang timbul karena pembagian kewenangan antara pusat dan daerah.

Mujahidin dan Wiredarme pada tahun 2020 meneliti tentang desentralisasi kewenangan bidang administrasi kependudukan dan pencatatan sipil. Penelitian ini hanya memfokuskan pada pembagian urusan pemerintahan yang sepenuhnya diselenggarakan oleh pemerintah tanpa asas desentralisasi dan urusan pemerintahan yang diselenggarakan dengan asas desentralisasi, tetapi tidak pernah secara eksklusif (sepenuhnya) menjadi wewenang daerah otonom. Belum ada analisis yang mendalam hanya perwujudan penyelenggaraan kewenangan desentralisasi dari aspek kelembagaan dan aspek pengelolaan personalia atau sumber daya manusia. Rekapitulasi penelitian terdahulu sebagaimana disajikan pada Tabel 1 .

Tabel 1. Penelitian tentang Administrasi Kependudukan dan Pencatatan Sipil Terdahulu

\begin{tabular}{|c|c|c|c|c|}
\hline No. & $\begin{array}{c}\text { Peneliti \& } \\
\text { Tahun }\end{array}$ & Judul & Hasil & Nilai Kritis \\
\hline 1. & $\begin{array}{l}\text { Abdul } \\
\text { Halik, } 2015\end{array}$ & $\begin{array}{l}\text { Implementasi } \\
\text { Kebijakan } \\
\text { Pelimpahan } \\
\text { Urusan } \\
\text { Pemerintahan } \\
\text { Lingkup } \\
\text { Kementerian } \\
\text { Dalam Negeri }\end{array}$ & $\begin{array}{l}\text { Secara umum } \\
\text { implementasi } \\
\text { kebijakan } \\
\text { dekonsentrasi di } \\
\text { Provinsi Jawa Barat } \\
\text { relatif sesuai dengan } \\
\text { target yang telah } \\
\text { ditetapkan. }\end{array}$ & $\begin{array}{l}\text { Sudah dilakukan analisis } \\
\text { faktor-faktor yang } \\
\text { menghambat } \\
\text { implementasi } \\
\text { kewenangan namun } \\
\text { hanya faktor internal } \\
\text { organisasi (teori Edward } \\
\text { III) belum menyentuh } \\
\text { faktor yang berasal dari } \\
\text { eksternal organisasi }\end{array}$ \\
\hline
\end{tabular}


Nakhoda: Jurnal Ilmu Pemerintahan

Vol. 19 No. 2 Tahun 2020 Halaman 128-150

e-ISSN: 2656-5277 | p-ISSN: 1829-5827

\begin{tabular}{|c|c|c|c|c|}
\hline No. & $\begin{array}{c}\text { Peneliti \& } \\
\text { Tahun }\end{array}$ & Judul & Hasil & Nilai Kritis \\
\hline 2. & $\begin{array}{l}\text { Mujahidin } \\
\text { dan } \\
\text { Wiredarme, } \\
2020\end{array}$ & $\begin{array}{l}\text { Desentralisasi } \\
\text { Kewenangan } \\
\text { Bidang } \\
\text { Administrasi } \\
\text { Kependudukan } \\
\text { dan Pencatatan } \\
\text { Sipil }\end{array}$ & $\begin{array}{l}\text { Sesuai UU No. } 23 \\
\text { Tahun } 2014 \text { sejumlah } \\
\text { urusan pemerintahan } \\
\text { telah diserahkan tetapi } \\
\text { urusan tersebut tidak } \\
\text { pernah secara } \\
\text { sepenuhnya menjadi } \\
\text { wewenang daerah } \\
\text { otonom }\end{array}$ & $\begin{array}{l}\text { Analisis faktor-faktor } \\
\text { yang menghambat } \\
\text { implementasi } \\
\text { kewenangan kurang } \\
\text { mendalam, hanya } \\
\text { pelaksanaan kewenangan } \\
\text { aspek kelembagaan dan } \\
\text { pengelolaan personalia }\end{array}$ \\
\hline 3. & $\begin{array}{l}\text { Lis } \\
\text { Febrianda, } \\
2009\end{array}$ & $\begin{array}{l}\text { Rekonstruksi } \\
\text { Regulasi } \\
\text { Pelayanan } \\
\text { Kependudukan } \\
\text { dan Pencatatan } \\
\text { Sipil oleh } \\
\text { Birokrasi } \\
\text { Pemerintahan } \\
\text { Dalam } \\
\text { Perspektif } \\
\text { Hukum } \\
\text { Administrasi } \\
\text { Negara }\end{array}$ & $\begin{array}{l}\text { aparat pelayanan } \\
\text { kependudukan dan } \\
\text { pencatatan sipil belum } \\
\text { mampu mengambil } \\
\text { tindakan diskresi, } \\
\text { peran birokrasi } \\
\text { pemerintah untuk } \\
\text { peningkatan kualitas } \\
\text { pelayanan sangat } \\
\text { penting, belum } \\
\text { terdapat asas-asas } \\
\text { umum pemerintahan } \\
\text { yang layak di dalam } \\
\text { UU No. 23/2006, } \\
\text { sehingga rekonstruksi } \\
\text { regulasi perlu } \\
\text { dilakukan }\end{array}$ & $\begin{array}{l}\text { Sudah dilakukan analisis } \\
\text { faktor-faktor yang } \\
\text { menghambat } \\
\text { implementasi } \\
\text { kewenangan pelayanan } \\
\text { dari faktor internal } \\
\text { maupun eksternal } \\
\text { organisasi namun lebih } \\
\text { fokus pada perspektif } \\
\text { hukum pelayanan }\end{array}$ \\
\hline
\end{tabular}

Sumber : Dokumen jurnal/disertasi. Data diolah. (2020)

\section{Metode}

Metode yang digunakan dalam penelitian ini adalah studi pustaka. Metode ini dapat dilihat sebagai cara sistematis untuk mengumpulkan data dan membuat sintesis dari studi masa lalu. Menurut (Snyder, 2019), studi pustaka merupakan metode penelitian yang menghasilkan landasan yang kokoh bagi kemajuan ilmu pengetahuan, termasuk pengembangan teori. Melalui review literatur, integrasi berbagai temuan dari penelitian sebelumnya akan menjadi upaya menjawab pertanyaan penelitian. Sedangkan pendekatan yang digunakan adalah integratif review di mana pengguna pendekatan ini melakukan penilaian, memberikan kritik, dan menyintesis studi sebelumnya tentang subjek studi tertentu.

Dalam penelitian ini, penulis mencoba menggali artikel jurnal, buku, peraturan pemerintah, dan sumber internet. Penulis juga menyintesis temuan penting sehingga dapat memberikan kebaruan untuk studi pelaksanaan kewenangan urusan administrasi kependudukan, sehingga pendekatan integratif review sangat relevan dengan penelitian ini. Objek penelitian dalam tulisan ini adalah Disdukcapil Prov. Kalteng di mana kewenangan urusan administrasi kependudukan sedang berjalan. Keberadaan Disdukcapil Prov. Kalteng sendiri didasarkan pada Peraturan Gubernur Kalimantan Tengah Nomor 40 Tahun 2016 Tentang Kedudukan, Susunan Organisasi, Tugas, Fungsi Dan Tata Kerja Dinas Kependudukan Dan Pencatatan Sipil Provinsi Kalimantan Tengah. 
Nakhoda: Jurnal Ilmu Pemerintahan

Vol. 19 No. 2 Tahun 2020 Halaman 128-150

e-ISSN: 2656-5277 | p-ISSN: 1829-5827

\section{Hasil dan Pembahasan}

\section{A. Perbedaan Kewenangan Administrasi Kependudukan antara Peraturan} Pemerintah 40/2019 dengan Undang-Undang 23/2014

Terdapat perbedaan yang cukup mendasar dalam UU 23/2014 yaitu belum mengakui dan melindungi para penghayat kepercayaan dan jumlah urusan administrasi kependudukan milik provinsi hanya sebatas penyusunan profil kependudukan provinsi (lampiran UU No. 23 Tahun 2014 hal. 51), sehingga jika dibentuk kantor disdukcapil provinsi tidak membentuk efektivitas dan efisiensi pemerintahan daerah. Kewenangan tersebut sebagaimana disajikan pada Tabel 2.

Tabel 2. Peta Kewenangan Pemerintah, Pemerintah Daerah Provinsi dan Kabupaten/Kota dalam Bidang Administrasi Kependudukan Menurut UU No. 23 Tahun 2014

\begin{tabular}{|c|c|c|c|c|}
\hline No. & Tugas & Ditjen Dukcapil & $\begin{array}{l}\text { Disdukcapil } \\
\text { Prov. }\end{array}$ & Disdukcapil Kab./Kota \\
\hline 1 & $\begin{array}{l}\text { Pendaftaran } \\
\text { Penduduk }\end{array}$ & 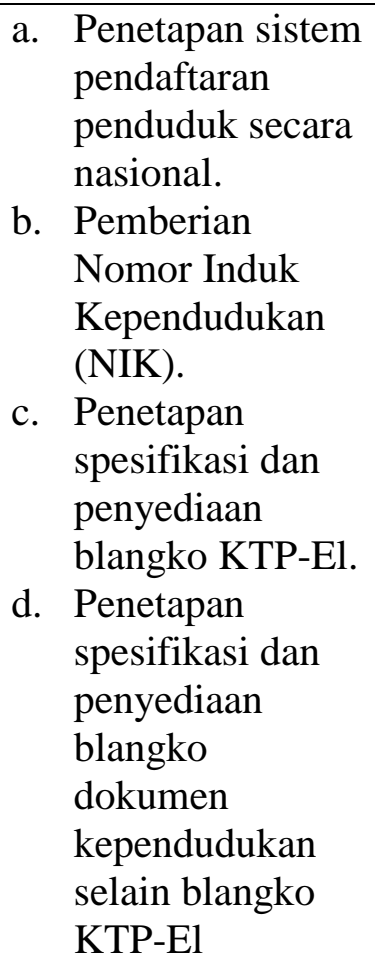 & -- & $\begin{array}{l}\text { Pelayanan pendaftaran } \\
\text { penduduk. }\end{array}$ \\
\hline 2 & $\begin{array}{l}\text { Pencatatan } \\
\text { Sipil }\end{array}$ & $\begin{array}{l}\text { a. Penetapan sistem } \\
\text { pencatatan sipil } \\
\text { secara nasional. } \\
\text { b. Penetapan } \\
\text { spesifikasi } \\
\text { blangko } \\
\text { dokumen } \\
\text { pencatatan sipil. }\end{array}$ & -- & $\begin{array}{l}\text { Pelayanan pencatatan } \\
\text { sipil. }\end{array}$ \\
\hline 3 & $\begin{array}{l}\text { Pengelolaan } \\
\text { Informasi } \\
\text { Administrasi } \\
\text { Kependudukan }\end{array}$ & $\begin{array}{l}\text { a. Verifikasi dan } \\
\text { validasi data } \\
\text { kependudukan } \\
\text { dari daerah } \\
\text { kabupaten/kota. } \\
\text { b. Pengelolaan dan } \\
\text { penyajian }\end{array}$ & -- & $\begin{array}{ll}\text { a. Pengumpulan } \\
\text { data } \\
\text { kependudukan. } \\
\text { b. Pemanfaatan dan } \\
\text { penyajian } \\
\text { database } \\
\text { kependudukan }\end{array}$ \\
\hline
\end{tabular}


Nakhoda: Jurnal Ilmu Pemerintahan

Vol. 19 No. 2 Tahun 2020 Halaman 128-150

e-ISSN: 2656-5277 | p-ISSN: 1829-5827

\begin{tabular}{lllll}
\hline No. & Tugas & Ditjen Dukcapil & $\begin{array}{c}\text { Disdukcapil } \\
\text { Prov. }\end{array}$ & Disdukcapil Kab./Kota \\
\hline & & $\begin{array}{l}\text { database } \\
\text { kependudukan } \\
\text { nasional. }\end{array}$ & & kabupaten/kota. \\
\hline 4 & $\begin{array}{l}\text { Profil } \\
\text { Kependudukan }\end{array}$ & $\begin{array}{l}\text { Penyusunan profil } \\
\text { kependudukan } \\
\text { nasional. }\end{array}$ & $\begin{array}{l}\text { Penyusunan } \\
\text { profil } \\
\text { kependudukan } \\
\text { provinsi. }\end{array}$ & $\begin{array}{l}\text { Penyusunan profil } \\
\text { kependudukan kab/kota. }\end{array}$ \\
\hline
\end{tabular}

Sumber : Dokumen lampiran UU No. 23 Tahun 2014. Data diolah. (2020)

Peta pembagian kewenangan administrasi kependudukan kementerian, provinsi dan kabupaten/kota menurut Peraturan Pemerintah Nomor 40 Tahun 2019 Tentang Pelaksanaan Undang-Undang Nomor 23 Tahun 2006 Tentang Administrasi Kependudukan, disajikan secara jelas pada Tabel 3.

Tabel 3. Peta Kewenangan Pemerintah, Pemerintah Daerah Provinsi dan Kabupaten/Kota dalam Bidang Administrasi Kependudukan Menurut PP No. 40 Tahun 2019

\begin{tabular}{|c|c|c|c|c|}
\hline No & Tugas & Ditjen Dukcapil & $\begin{array}{c}\text { Disdukcapil } \\
\text { Prov. }\end{array}$ & $\begin{array}{c}\text { Disdukcapil } \\
\text { Kab./Kota }\end{array}$ \\
\hline 1 & $\begin{array}{l}\text { Koordinasi } \\
\text { antar instansi } \\
\text { dan antar } \\
\text { daerah; }\end{array}$ & $\begin{array}{ll}\text { a. } & \text { Melibatkan } \\
\text { kementerian/lembaga } \\
\text { terkait, Pemerintah } \\
\text { Daerah provinsi dan } \\
\text { kabupaten/kota; } \\
\text { b. Lintas kementerian } \\
\text { urusan hubungan luar } \\
\text { negeri. }\end{array}$ & $\begin{array}{l}\text { Antar lembaga } \\
\text { Pemerintah dan } \\
\text { lembaga non- } \\
\text { Pemerintah di } \\
\text { provinsi dan antar } \\
\text { kabupaten/kota; }\end{array}$ & $\begin{array}{l}\text { a. Dengan } \\
\text { kantor } \\
\text { kementerian } \\
\text { agama } \\
\text { kab/kota dan } \\
\text { pengadilan } \\
\text { agama bagi } \\
\text { Penduduk } \\
\text { yang } \\
\text { beragama } \\
\text { Islam; } \\
\text { b. Pembinaan } \\
\text { instansi } \\
\text { vertikal dan } \\
\text { UPT Dinas } \\
\text { Kependuduka } \\
\text { n dan } \\
\text { Pencatatan } \\
\text { Sipil; }\end{array}$ \\
\hline 2 & $\begin{array}{l}\text { Penetapan } \\
\text { sistem, } \\
\text { pedoman, dan } \\
\text { standar; }\end{array}$ & $\begin{array}{l}\text { a. Penyelenggaraan SIAK; } \\
\text { b. Perencanaan, } \\
\text { pelaksanaan, } \\
\text { pemantauan, evaluasi, } \\
\text { dan pengendalian; } \\
\text { c. Perlindungan data } \\
\text { penduduk; } \\
\text { d. Pengelolaan dan } \\
\text { pendistribusian blangko } \\
\text { KTP-el; } \\
\text { e. Pemanfaatan data dan }\end{array}$ & $\begin{array}{l}\text { Penyusunan tata } \\
\text { cara perencanaan, } \\
\text { pelaksanaan, } \\
\text { pemantauan, } \\
\text { evaluasi, dan } \\
\text { pengendalian } \\
\text { urusan } \\
\text { administrasi } \\
\text { kependudukan; } \\
\text { dan pengelolaan } \\
\text { data }\end{array}$ & $\begin{array}{l}\text { Penyusunan tata } \\
\text { cara } \\
\text { perencanaan, } \\
\text { pelaksanaan, } \\
\text { pemantauan, } \\
\text { evaluasi, dan } \\
\text { pengendalian } \\
\text { urusan } \\
\text { administrasi } \\
\text { kependudukan; }\end{array}$ \\
\hline
\end{tabular}




\begin{tabular}{|c|c|c|c|c|}
\hline No & Tugas & Ditjen Dukcapil & $\begin{array}{c}\text { Disdukcapil } \\
\text { Prov. }\end{array}$ & $\begin{array}{c}\text { Disdukcapil } \\
\text { Kab./Kota }\end{array}$ \\
\hline & & 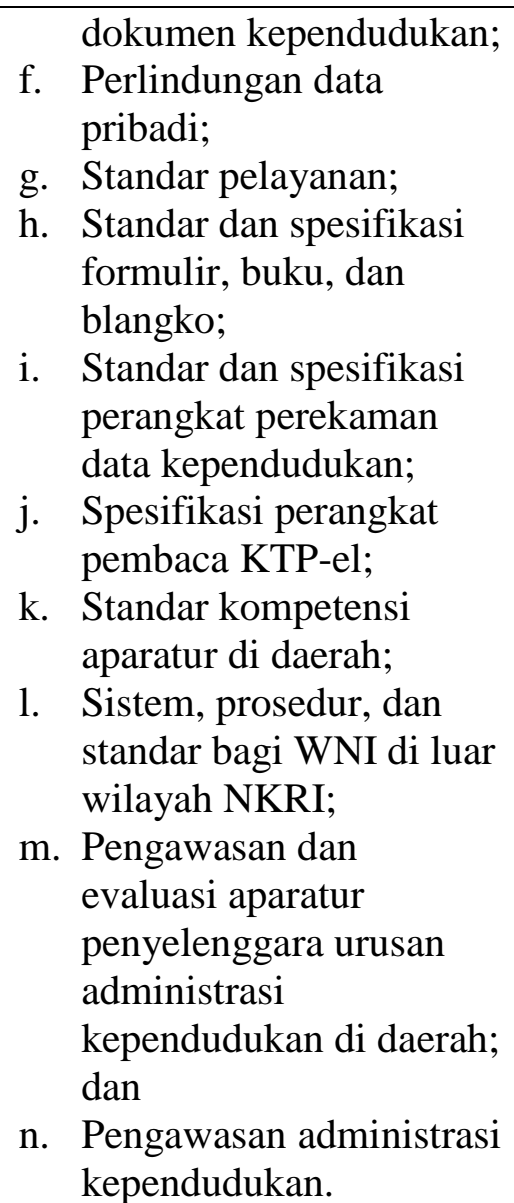 & $\begin{array}{l}\text { kependudukan } \\
\text { yang bersifat data } \\
\text { perseorangan, data } \\
\text { agregat, dan data } \\
\text { pribadi di provinsi } \\
\text { dan } \\
\text { kabupaten/kota; }\end{array}$ & \\
\hline 3 & $\begin{array}{l}\text { Pengadaan } \\
\text { blangko } \\
\text { dokumen } \\
\text { kependudukan }\end{array}$ & $\begin{array}{l}\text { - } \text { Menyediakan blangko } \\
\text { KTP-el bagi } \\
\text { kabupaten/kota; } \\
\text { - } \text { Menyediakan blangko } \\
\text { dokumen kependudukan } \\
\text { selain blangko KTP-el } \\
\text { bagi Perwakilan } \\
\text { Republik Indonesia; } \\
\text { - } \\
\text { Menetapkan standar \& } \\
\text { spesifikasi dokumen } \\
\text { kependudukan berupa: } \\
\text { biodata Penduduk; KK; } \\
\text { akta pencatatan sipil; } \\
\text { kartu identitas anak; dan } \\
\text { surat keterangan } \\
\text { kependudukan. }\end{array}$ & -- & $\begin{array}{l}\text { Menyediakan } \\
\text { selain blangko } \\
\text { KTP-el, } \\
\text { formulir, dan } \\
\text { buku untuk } \\
\text { pelayanan } \\
\text { pendaftaran } \\
\text { penduduk dan } \\
\text { pencatatan sipil }\end{array}$ \\
\hline 4 & $\begin{array}{l}\text { Pengelolaan } \\
\text { dan pelaporan }\end{array}$ & -- & -- & $\begin{array}{l}\text { Pengelolaan dan } \\
\text { pelaporan } \\
\text { penggunaan } \\
\text { blangko } \\
\text { dokumen } \\
\text { kependudukan, } \\
\text { formulir, dan }\end{array}$ \\
\hline
\end{tabular}




\begin{tabular}{|c|c|c|c|c|c|}
\hline No & Tugas & Ditjen Dukcapil & & $\begin{array}{c}\text { Disdukcapil } \\
\text { Prov. }\end{array}$ & $\begin{array}{c}\text { Disdukcapil } \\
\text { Kab./Kota }\end{array}$ \\
\hline & & & & & $\begin{array}{l}\text { buku untuk } \\
\text { pelayanan } \\
\text { pendaftaran } \\
\text { penduduk dan } \\
\text { pencatatan sipil; }\end{array}$ \\
\hline 5 & $\begin{array}{l}\text { Pembinaan, } \\
\text { pembimbingan, } \\
\text { supervisi, } \\
\text { pemantauan, } \\
\text { evaluasi, dan } \\
\text { konsultasi } \\
\text { mengenai } \\
\text { administrasi } \\
\text { kependudukan; }\end{array}$ & $\begin{array}{l}\text { a. Melaksanakan } \\
\text { pembinaan } \\
\text { penyelenggaraan urusan } \\
\text { administrasi } \\
\text { kependudukan meliputi: } \\
\text { 1. menetapkan standar } \\
\text { sumber daya manusia } \\
\text { pelaksana; } \\
\text { 2. pembinaan aparatur } \\
\text { penyelenggara; dan } \\
\text { 3. pendokumentasian. } \\
\text { b. Melaksanakan } \\
\text { bimbingan teknis dan } \\
\text { pelatihan; } \\
\text { c. Melaksanakan supervisi } \\
\text { penyelenggaraan; } \\
\text { d. Memberikan konsultasi } \\
\text { pelaksanaan; } \\
\text { e. Melaksanakan } \\
\text { pemantauan dan evaluasi } \\
\text { penyelenggaraan. }\end{array}$ & - & $\begin{array}{l}\text { pembinaan } \\
\text { pendokumenta } \\
\text { sian } \\
\text { penyelenggara } \\
\text {; } \\
\text { pemantauan, } \\
\text { evaluasi dan } \\
\text { konsultasi: } \\
\text { penyelenggara } \\
\text {; } \\
\text { supervisi, } \\
\text { verifikasi dan } \\
\text { validasi data } \\
\text { kependudukan } \\
\text {; } \\
\text { - bimbingan } \\
\text { teknis } \\
\text { pendaftaran } \\
\text { penduduk, } \\
\text { pencatatan } \\
\text { sipil, } \\
\text { pengelolaan } \\
\text { informasi } \\
\text { kependudukan } \\
\text { \& \& } \\
\text { pendayagunaa } \\
\text { n data } \\
\text { kependudukan }\end{array}$ & $\begin{array}{l}\text { - UPT Dinas } \\
\text { Kependuduk } \\
\text { an dan } \\
\text { Pencatatan } \\
\text { Sipil; } \\
\text { penugasan } \\
\text { kepala desa } \\
\text { atau yang } \\
\text { disebut } \\
\text { dengan nama } \\
\text { lain } \\
\text { supervisi } \\
\text { dengan } \\
\text { kantor } \\
\text { kementerian } \\
\text { agama dan } \\
\text { pengadilan } \\
\text { agama bagi } \\
\text { penduduk } \\
\text { yang } \\
\text { beragama } \\
\text { Islam }\end{array}$ \\
\hline
\end{tabular}

6 Fasilitasi, sosialisasi, komunikasi, informasi, dan edukasi

\section{a. Fasilitasi} penyelenggaraan urusan administrasi kependudukan;

b. Sosialisasi administrasi kependudukan;

c. Kerja sama dengan pihak terkait; dan

d. Komunikasi, informasi, dan edukasi kepada pemangku kepentingan dan masyarakat.

$\begin{array}{ll}\text { Penyelenggaraan } & \text { Penyelenggaraan } \\ \text { urusan } & \text { urusan } \\ \text { administrasi } & \text { administrasi } \\ \text { kependudukan } & \text { kependudukan } \\ \text { kepada pemangku } & \text { kepada } \\ \text { kepentingan dan } & \text { pemangku } \\ \text { masyarakat; } & \begin{array}{l}\text { kepentingan dan } \\ \text { masyarakat; }\end{array}\end{array}$

Penyelenggaraan

urusan kepada pemangku kepentingan dan

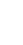

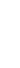

\author{
buku untuk \\ pelayanan \\ pendaftaran \\ penduduk dan \\ pencatatan sipil;
}


Nakhoda: Jurnal Ilmu Pemerintahan

Vol. 19 No. 2 Tahun 2020 Halaman 128-150

e-ISSN: 2656-5277 | p-ISSN: 1829-5827

\begin{tabular}{|c|c|c|c|c|}
\hline No & Tugas & Ditjen Dukcapil & $\begin{array}{c}\text { Disdukcapil } \\
\text { Prov. }\end{array}$ & $\begin{array}{c}\text { Disdukcapil } \\
\text { Kab./Kota }\end{array}$ \\
\hline & $\begin{array}{l}\text { perlindungan } \\
\text { data } \\
\text { kependudukan } \\
\text { \& dokumen } \\
\text { kependudukan; }\end{array}$ & $\begin{array}{l}\text { akses kepada } \\
\text { kementerian; } \\
\text { lembaga; dan badan } \\
\text { hukum Indonesia. } \\
\text { - } \\
\text { Berhak mendapatkan } \\
\text { data balikan setelah } \\
\text { hak akses } \\
\text { dimanfaatkan oleh } \\
\text { pengguna. }\end{array}$ & $\begin{array}{l}\text { dengan organisasi } \\
\text { kemasyarakatan \& } \\
\text { perguruan tinggi } \\
\text { tingkat provinsi }\end{array}$ & $\begin{array}{l}\text { dengan } \\
\text { organisasi } \\
\text { kemasyarakatan } \\
\text { dan perguruan } \\
\text { tinggi kab/kota }\end{array}$ \\
\hline 8 & $\begin{array}{l}\text { Pengelolaan } \\
\text { dan penyajian } \\
\text { data } \\
\text { kependudukan }\end{array}$ & $\begin{array}{ll}\text { a. } & \text { Pengelolaan data } \\
\text { perseorangan, data } \\
\text { agregat, dan data pribadi } \\
\text { di pusat, pemda } \\
\text { provinsi, \& pemda } \\
\text { kabupaten/kota; } \\
\text { b. Penyajian data akurat \& } \\
\text { dapat dipertanggung } \\
\text { jawabkan. }\end{array}$ & $\begin{array}{l}\text { Penyajian data } \\
\text { akurat \& dapat } \\
\text { dipertanggung } \\
\text { jawabkan. }\end{array}$ & $\begin{array}{l}\text { Penyajian data } \\
\text { akurat \& dapat } \\
\text { dipertanggung } \\
\text { jawabkan. }\end{array}$ \\
\hline 9 & Pengawasan & $\begin{array}{l}\text { Pengawasan urusan } \\
\text { administrasi kependudukan } \\
\text { nasional }\end{array}$ & $\begin{array}{l}\text { Pengawasan } \\
\text { administrasi } \\
\text { kependudukan } \\
\text { provinsi. }\end{array}$ & $\begin{array}{l}\text { Pengawasan } \\
\text { administrasi } \\
\text { kependudukan } \\
\text { kabupaten/kota. }\end{array}$ \\
\hline
\end{tabular}

Sumber : Dokumen PP No. 40 Tahun 2019. Data diolah. (2020)

PP No. 40 Tahun 2019 telah menegaskan komitmen negara yang mengakui dan wajib melindungi para penghayat kepercayaan. Dalam regulasi tersebut, khususnya Bab VI diatur jelas tata cara pencatatan perkawinan bagi penghayat kepercayaan terhadap Tuhan Yang Maha Esa sehingga tidak boleh ada lagi muncul masalah diskriminasi berkaitan pelayanan pencatatan administrasi kependudukan khususnya bagi para penghayat kepercayaan. Dalam PP No. 40 Tahun 2019 terlihat banyak peran yang harus dilaksanakan pemerintah pusat, provinsi maupun kabupaten/kota namun bila diteliti lebih jauh perannya hanya mendetail bagi kementerian sedangkan bagi provinsi dan kabupaten/kota masih diatur secara garis besar sehingga rawan terjadi multitafsir jika provinsi dan kabupaten/kota mengerjakan urusannya. Kementerian lebih diuntungkan melalui uraian tugas yang jelas dan cenderung menjadi otoriter karena memegang urusan vital bagi pelayanan disdukcapil kabupaten/kota. Hal senada menurut (Robuwan et al., 2018) bahwa penghambat utama pelaksanaan urusan administrasi kependudukan ialah cara pandang pemerintah pusat sendiri yang menilai pemerintah daerah adalah bawahan sehingga hal ini membatasi kemampuan dan potensi masing-masing daerah untuk berkembang (hierarkis-dominatif).

Berdasarkan Tabel 3 di atas, terlihat jelas pelimpahan kewenangan administrasi kependudukan telah merata kepada pemerintah provinsi maupun kabupaten/kota, akan tetapi bukan kewenangan yang sifatnya penting, misalnya pengadaan blangko dokumen kependudukan maupun pengawasan penyelenggaraan kewenangan administrasi kependudukan. Dalam hal ini penulis menilai pemerintah memberikan otonomi daerah yang terbatas. Hal ini didukung oleh (Said, 2015), ia mengungkapkan pusat telah membagi kewenangan dan menentukan norma, pedoman, standar, dan kriteria yang ketat dalam pelaksanaan sehingga bersifat mengikat bagi pemerintah daerah. Apabila tidak diimplementasikan sesuai aturan maka akan dianggap sebagai pelanggaran dan diberikan 
Nakhoda: Jurnal Ilmu Pemerintahan

Vol. 19 No. 2 Tahun 2020 Halaman 128-150

e-ISSN: 2656-5277 | p-ISSN: 1829-5827

peringatan. Hal ini merupakan ciri dari pembatasan kewenangan otonomi daerah dalam UU $23 / 2014$

Hal di atas diperkuat (Indah, 2014) bahwa otonomi terbatas terjadi bila urusanurusan pemerintahan daerah telah dibagi sesuai kategori dan dilaksanakan sesuai dengan ketentuan dan aturan yang berlaku sehingga tanpa pengawasan pusat, pemerintah daerah seperti kehilangan kemampuan untuk mengurus dan mengatur rumah tangga daerahnya. Otonomi terbatas saling membenturkan pelaksanaan kewenangan administrasi kependudukan antara pusat dan daerah. Salah satu contoh kasus di Disdukcapil Prov. Kalteng, koordinator wilayah (Korwil) dalam (Rina Wahyuni, 2015) sering meminta laporan kependudukan dengan berbagai format dan melaksanakan rapat koordinasi tanpa memberikan feedback mengenai hal-hal yang mestinya diperbaiki ke depan oleh disdukcapil provinsi dan kab/kota. Koordinator wilayah (Korwil) Direktorat Jenderal Kependudukan dan Pencatatan Sipil (Ditjen Dukcapil) Kementerian Dalam Negeri merupakan penanggung jawab provinsi setingkat pejabat eselon 4 yang memiliki tugas utama memberikan fasilitasi dan pendampingan teknis bagi provinsi dan kabupaten/kota selaku pelaksana pelayanan secara langsung kepada masyarakat. Tetapi dalam pelaksanaan tugas sehari-hari Korwil sering memberikan pekerjaan tambahan berupa laporan data kependudukan dalam format terbaru yang diinginkannya. Hal ini sangat mengganggu karena Ditjen memiliki database kependudukan se-Indonesia yang menghitung secara real time jumlah penduduk. Konflik ini terjadi karena antara Korwil 1 sampai dengan 5 belum menerapkan knowledge management system yang baik sehingga belum tercipta manajemen pengetahuan di Ditjen Dukcapil.

Peran Korwil cenderung mementingkan urusan pusat, dan praktik administrasi pemerintah yang keliru di mana disdukcapil provinsi merasa seperti memiliki dua pimpinan yakni dirjen dukcapil dan gubernur. Konflik tersebut berdampak terhadap dualisme administrasi pemerintahan, konflik horizontal (jika perintah Korwil tidak diindahkan) dan sesama aparatur pemerintah.

Sehingga berdasar uraian di atas dapat kita katakan bahwa sebagian kewenangan dalam PP No. 40 Tahun 2019 telah mengurangi kewenangan pemerintah kabupaten/kota yang notabene merupakan titik berat pelaksanaan otonomi daerah dan ini semakin memperkuat sinyalemen terjadinya pemusatan (resentralisasi) kewenangan yang mengarah ke pemerintah pusat (kementerian) (Wicaksono, 2012; Yusdianto, 2015). Pada zaman orde baru pemerintah mengeruk SDA daerah secara berlebihan dengan alasan pemerataan pembangunan, pusat sebagai penggerak utama dan menikmati hasil pembangunan. Sentralisasi justru memiskinkan daerah karena tidak mendapatkan hasil yang setimpal dari pembangunan (Patawari, 2012). Senada dengan persoalan tersebut, penulis mengidentifikasi setidaknya dua isu pokok (dari 7 isu Dwiyanto) problematika pelaksanaan urusan administrasi kependudukan. Pertama, distorsi dalam pelaksanaan asas penyelenggaraan pemerintahan daerah. Kedua, perubahan distribusi urusan pemerintahan dan kriteria pembagian urusan.

\section{B. Potensi Hambatan}

a) Hambatan Distorsi Dalam Pelaksanaan Asas Penyelenggaraan Pemerintahan Daerah

Permasalahan yang timbul terkait isu pertama antara lain benturan regulasi dan kerancuan penerapan asas dekonsentrasi/tugas pembantuan. Penyelenggaraan wewenang administrasi kependudukan menganut dua asas yakni tugas pembantuan untuk kabupaten/kota dan dekonsentrasi (dekon) untuk provinsi (Simandjuntak, 2016). Sejak berlakunya Peraturan Menteri Dalam Negeri Nomor 102 Tahun 2016 Tentang Petunjuk 
Nakhoda: Jurnal IImu Pemerintahan

Vol. 19 No. 2 Tahun 2020 Halaman 128-150

e-ISSN: 2656-5277 | p-ISSN: 1829-5827

Teknis Penggunaan Dana Alokasi Khusus Non Fisik Dana Pelayanan Administrasi Kependudukan sampai sekarang, dana dekonsentrasi/tugas pembantuan telah diubah menjadi DAK non fisik pelayanan administrasi kependudukan, yang mekanisme pembayarannya berupa transfer langsung ke APBD pemerintah daerah sehingga harus dikelola dan dipertanggungjawabkan sesuai aturan daerah. Terjadi benturan regulasi artinya dalam penyelenggaraan administrasi kependudukan, posisi kementerian teknis/sektoral menjadi steering (pengarah) dengan memberikan aturan ketat terhadap semua urusan administrasi kependudukan yang telah diserahkan membuat kementerian sebagai pemegang kewenangan tertinggi (Nur Wijayanti, 2016) sehingga disdukcapil provinsi maupun kabupaten/kota tidak dapat mengambil tindakan diskresi guna mengatasi permasalahan pelayanan (Febrianda, 2009).

Pengaturan kementerian melalui perundang-undangan, petunjuk pelaksanaan dan petunjuk teknis sudah cukup ketat dan dalam penyusunannya pun dirasakan lebih condong top down daripada bottom up. Hal ini bisa dilihat dari sejumlah kebijakan kementerian yang hanya fokus pada pelaksanaan kegiatan tanpa mengakomodir potensi daerah (Albintani \& Marta, 2020) dan keterbatasan suatu daerah (Ekwarso \& Sari, 2010; Rauf, 2018b). Benturan regulasi di mana provinsi tidak mempunyai peranan yang nyata dalam menekan jumlah PRR (print ready record) di disdukcapil kab/kota atau data siap cetak yang menunggu ketersediaan blangko KTP-el dari kementerian. Dapat dilihat pada Tabel 6. Laporan Perkembangan KTP-el, Akta Kelahiran, dan Akta Kematian Bulan Februari 2020, PRR (print ready record) masih tinggi berjumlah 24.971 orang dan Tabel 5. Data Perekaman Penduduk Kalimantan Tengah Per 19 November 2020 bahwa 79.220 orang belum melakukan perekaman KTP-el. Benturan regulasi tingkat kabupaten/kota yang secara nyata terjadi, bahwa pemda tidak mempunyai peranan nyata dalam mempercepat pelayanan KTP-el karena jumlah blangko KTP-el yang terbatas dari pengadaan kementerian (Pamungkas \& Fitriati, 2019). Hal ini relevan dengan model agensi yang diajukan (Indah, 2014) bahwa pemerintah pusat mewajibkan pemerintahan daerah menjadi agen pelaksana kebijakannya melalui peraturan perundang-undangan dan pengawasan kegiatan yang ketat.

Kemudian kerancuan penerapan asas dekonsentrasi/tugas pembantuan tampak di lapangan, disdukcapil provinsi maupun kabupaten/kota tidak didukung dengan penganggaran yang memadai (Rauf, 2018b). Anggaran DAK non fisik yang kecil menyebabkan daerah kesulitan untuk melaksanakan berbagai kewenangan yang dilimpahkan padahal anggaran merupakan instrumen penting pengembangan kapabilitas dan efektivitas daerah (Ismail, 2019). Pemerintah pusat memberikan banyak kewenangan yang lemah dengan anggaran yang minim. Sebagai bukti Anggaran Disdukcapil Prov. Kalteng dapat dilihat pada Tabel 4.

Tabel 4. Anggaran Belanja Langsung Disdukcapil Prov. Kalteng

\begin{tabular}{ccr}
\hline No. & Tahun & Pagu Belanja Langsung (Rp) \\
\hline 1 & 2017 & 4.195 .861 .900 \\
2 & 2018 & 6.054 .036 .968 \\
3 & 2019 & 10.856 .394 .070 \\
4 & 2020 & 2.333 .077 .830 \\
\hline
\end{tabular}

Sumber : Dokumen Rencana Kerja. Data diolah. (2020)

Bila dilihat anggaran Disdukcapil Prov. Kalteng dalam 4 (empat) tahun terakhir peningkatan tertinggi hanya terjadi tahun 2019 sebesar Rp. 10.856.394.070,-. Anggaran ini digunakan untuk pengadaan alat rekam dan cetak e-KTP bagi 14 kabupaten/kota di Prov. Kalteng yang berasal dari APBD (Kebijakan Pengadaan Barang/Jasa Pemerintah, 2020). 
Nakhoda: Jurnal IImu Pemerintahan

Vol. 19 No. 2 Tahun 2020 Halaman 128-150

e-ISSN: 2656-5277 | p-ISSN: 1829-5827

Sesuai Peraturan Presiden Republik Indonesia Nomor 26 Tahun 2009 Tentang Penerapan Kartu Tanda Penduduk Berbasis Nomor Induk Kependudukan Secara Nasional Ayat 3 Angka 1, bahwa pemerintah hanya menghibahkan 1 (satu) kali perangkat keras dan lunak penerapan KTP-el kepada pemerintah daerah. Pengadaan alat rekam dan cetak e-KTP bagi 14 kabupaten/kota ini penting digunakan untuk persiapan Pemilihan Umum Kepala Daerah Serentak Tahun 2020 di Kalimantan Tengah. Seharusnya setiap tahun jumlah APBD urusan adminduk harus berimbang dengan jumlah dana transfer DAK non fisik pelayanan administrasi kependudukan, tetapi karena Tim Anggaran Pemerintah Daerah Prov. Kalteng salah menafsirkan tugas disdukcapil yang melaksanakan dekonsentrasi dari pusat dan juga keterbatasan APBD (Prihatiningsih et al., 2013) maka pembiayaan kegiatan mayoritas berasal dari DAK non fisik. APBD terbatas hanya digunakan untuk membiayai kegiatan kesekretariatan seperti gaji, perencanaan kegiatan dan keuangan, operasional kantor, tata usaha pimpinan dan perlengkapan dan pembiayaan lainnya yang bersifat menambah belanja modal atau aset bagi daerah (Prihatiningsih et al., 2013).

Menurut (PKP2A III LAN, 2007) hal ini disebabkan dalam proses perencanaan anggaran terjadi ketidaksinkronan antara usulan kegiatan daerah dengan anggaran yang telah ditetapkan oleh kementerian, terjadi perubahan terhadap besaran nominal. Sehingga dalam operasionalisasi program yang direncanakan berdasarkan kebutuhan dan kondisi daerah tidak dapat secara optimal terlaksanakan. Hal ini membawa efek psikologis, melemahkan motivasi daerah karena perencanaan yang telah disusun ternyata tidak dijadikan sebagai acuan dalam penetapan program. Sistem perencanaan yang tidak terintegrasi antara perencanaan pusat dengan perencanaan daerah berimplikasi kepada tingkat pembiayaan penyelenggaraan kewenangan administrasi kependudukan di daerah. Sedangkan DAK Non Fisik hanya digunakan khusus pelayanan non fisik meliputi koordinasi, pembinaan, fasilitasi, dan bimtek mengenai kebijakan administrasi kependudukan dan pencatatan sipil kepada kabupaten/kota. Serta konsultasi ke Ditjen Dukcapil RI mengenai kendala pelayanan administrasi kependudukan. Ketergantungan daerah pada transfer pusat menimbulkan kejanggalan dalam pelaksanaan otonomi daerah (Nugraha \& Dwirandra, 2016; E. T. I. Sari \& Asyik, 2017; Setiaji \& Adi, 2007) dan belanja daerah tidak sebanding dengan Pendapatan Asli Daerah (Sasana, 2011; Setiaji \& Adi, 2007).

Dampak dari komposisi DAK Non Fisik lebih kecil dari APBD, terlihat pada ketidakmampuan provinsi memfasilitasi seluruh pelayanan administrasi kependudukan di kabupaten/kota setiap tahunnya. Sesuai Surat Edaran Dirjen Dukcapil Nomor 471.13/14651/DUKCAPIL tanggal 10 November 2017 Hal Pengadaan Perangkat Kartu Tanda Penduduk Elektronik, memerintahkan agar pemerintah provinsi segera melakukan pengadaan perangkat keras dan lunak pelayanan administrasi kependudukan bagi kabupaten/kota padahal APBD provinsi sangat terbatas. Pelayanan disdukcapil provinsi dalam memfasilitasi disdukcapil kabupaten/kota tidak akan bertambah baik jika tidak didukung dengan anggaran yang memadai. Hal ini disebabkan, 14 kabupaten/kota di Kalimantan Tengah alat rekam cetak e-KTP dan peralatan Sistem Informasi Administrasi Kependudukan sudah usang, sarana dan prasarana pelayanan kurang memadai, SDM aparat yang kurang cakap karena keterbatasan ketersediaan dana untuk bimtek/diklat, birokrasi yang rumit, merupakan sebagian akibat yang disebabkan wewenang tidak didukung anggaran.

Hal ini diperparah oleh Tim Anggaran Pemerintah Daerah kabupaten/kota yang juga salah paham terhadap peran disdukcapil melaksanakan tugas pembantuan dari pusat sehingga pembiayaan kegiatan mayoritas berasal dari DAK non fisik dan minim dukungan APBD. Sehingga tepat jika (Indah, 2014) dalam penelitiannya menyatakan keterbatasan kewenangan yang dilimpahkan oleh pusat membuat daerah otonom kesulitan dalam 
Nakhoda: Jurnal Ilmu Pemerintahan

Vol. 19 No. 2 Tahun 2020 Halaman 128-150

e-ISSN: 2656-5277 | p-ISSN: 1829-5827

mengembangkan pendapatan asli daerahnya. Harusnya pusat bukan hanya memberikan aturan mengenai pedoman pelaksanaan dan standar keberhasilan tetapi juga memberikan perhatian berupa anggaran, peralatan, sarana dan prasarana serta SDM guna mendukung implementasi urusan administrasi kependudukan yang sedang berjalan (Rauf, 2018b). Kerancuan penerapan asas dekonsentrasi/tugas pembantuan menyebabkan pelayanan administrasi kependudukan belum menjadi lebih baik, masih berada di bawah standar ketetapan nasional. Hal ini bukan tanpa alasan berdasarkan data pelayanan KTP-el per 19 November 2020 pada Tabel 5.

Tabel 5. Data Perekaman Penduduk Kalimantan Tengah per 19 November 2020

\begin{tabular}{rlrrrrr}
\hline No. & $\begin{array}{c}\text { Kabupaten } \\
\text { / Kota }\end{array}$ & $\begin{array}{c}\text { Jumlah } \\
\text { Penduduk }\end{array}$ & $\begin{array}{c}\text { Wajib KTP } \\
\text { Smtr 1 2020 }\end{array}$ & \multicolumn{1}{c}{ Rekam } & $\begin{array}{c}\text { Belum } \\
\text { Rekam }\end{array}$ & \multicolumn{1}{c}{$\%$} \\
\hline 1 & Kotawaringin Barat & 255.346 & 181.844 & 190.792 & - & 104,92 \\
2 & Kotawaringin & 415.702 & 292.729 & 279.200 & 13.529 & 95,38 \\
& Timur & 416.865 & 301.553 & 263.323 & 38.230 & 87,32 \\
3 & Kapuas & 93.994 & 100.593 & - & 107,02 \\
4 & Barito Selatan & 130.302 & 111.261 & 104.847 & 6.414 & 94,24 \\
5 & Barito Utara & 156.724 & 107.430 & 107.969 & 539 & 100,50 \\
6 & Katingan & 158.449 & 102.233 & 98.323 & 3.910 & 96,18 \\
7 & Seruyan & 148.666 & 43.097 & 45.303 & - & 105,12 \\
8 & Sukamara & 61.881 & 67.769 & 68.654 & - & 101,31 \\
9 & Lamandau & 93.179 & 92.702 & 76.199 & 16.503 & 82,20 \\
10 & Gunung Mas & 135.901 & 93.505 & 91.996 & 1.509 & 98,39 \\
11 & Pulang Pisau & 133.209 & 72.508 & 73.293 & - & 101,08 \\
12 & Murung Raya & 110.277 & 83.008 & 78.696 & 4.312 & 94,81 \\
13 & Barito Timur & 114.316 & 192.554 & 197.202 & 4.648 & 102,41 \\
14 & Palangka Raya & 271.302 & 1.836 .187 & 1.776 .390 & 79.220 & 96,74 \\
\hline & Total Prov. Kalteng & 2.602 .119 & & & \\
\hline
\end{tabular}

Sumber : Dokumen Laporan Data Kependudukan. Data diolah. (2020)

Berdasarkan data di atas, masih terdapat 79.220 orang yang belum melakukan perekaman KTP-el padahal pada tanggal 9 Desember 2020 dilaksanakan Pemilihan Gubernur Kalimantan Tengah. Menurut (Febrianda, 2009) dalam disertasinya menyatakan Undang-Undang Nomor 23 Tahun 2006 Tentang Administrasi Kependudukan serta aturan turunan lainnya masih menggunakan pendekatan legalistik-positivistik sehingga aparatur negara tidak mampu mengambil tindakan diskresi mengatasi permasalahan dan belum menerapkan prinsip-prinsip hukum pelayanan publik yang baik. Terjadinya ketidakadilan dalam memberikan pelayanan, ketidakpastian pelayanan, ketidakwajaran biaya pelayanan, dan mal-administrasi berimplikasi pada rendahnya capaian asas-asas umum pemerintahan yang layak. Kementerian mempunyai tangan panjang di provinsi untuk mengontrol kewenangan administrasi kependudukan, dalam UU 23/2014 disebutkan gubernur adalah wakil pemerintah pusat di daerah akan tetapi tetap saja gubernur merupakan wakil yang dipilih oleh rakyat secara langsung bukan hasil penunjukan pemerintah pusat (Kristiyanto, 2012). Sehingga wajar jika pemda lebih mengutamakan urusan yang menyejahterakan warganya secara langsung daripada mengerjakan kewenangan yang menjadi milik pusat di daerah. 
Nakhoda: Jurnal IImu Pemerintahan

Vol. 19 No. 2 Tahun 2020 Halaman 128-150

e-ISSN: 2656-5277 | p-ISSN: 1829-5827

\section{b) Hambatan Distribusi Urusan Administrasi Kependudukan dan Kriteria Pembagian Urusan}

Isu yang kedua tentang distribusi urusan administrasi kependudukan, manakala kementerian mengerjakan tugas yang sama dengan tugas yang telah diserahkan ke daerah dan pemerintah daerah pun telah melaksanakan tugas tersebut. Sebagai contoh, urusan pelaporan data kependudukan KTP-el, akta kelahiran, akta kematian dan penggunaan blangko dokumen kependudukan setiap bulan (tabel 1, poin 4 dan 8). Tugas tersebut telah dikerjakan disdukcapil kabupaten/kota, dan disdukcapil provinsi selaku wakil pemerintah pusat dituntut melaksanakan tugas yang tidak tertuang dalam PP untuk melaporkan dan merekapitulasi data. Memang pelaporan ini sering kali terlambat dari tanggal yang telah ditetapkan dengan berbagai alasan. Namun pada saat yang sama kementerian juga memiliki laporan melalui aplikasi Pengelolaan Data Administrasi Kependudukan (PDAK) yang memantau data pelayanan se-Indonesia secara otomatis setiap hari. Data kabupaten/kota kemungkinan hanya dipakai sebagai data pembanding saja dengan aplikasi yang diilustrasi pada gambar 1 berikut :

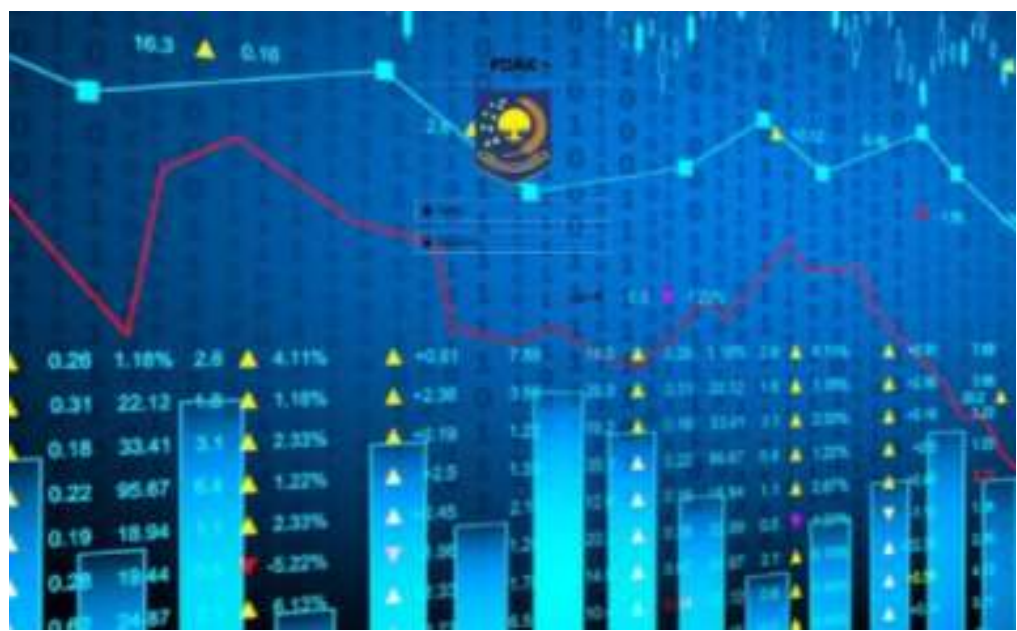

Gambar 1. Aplikasi Pengelolaan Data Administrasi Kependudukan (PDAK)

Permasalahan selanjutnya adalah lemahnya pengawasan provinsi terhadap pelaksanaan administrasi kependudukan di kabupaten/kota (Halik, 2015). Lemahnya pengawasan ketika disdukcapil provinsi memberikan teguran kepada disdukcapil kab/kota yang tidak melaksanakan pelayanan dengan baik. Disdukcapil provinsi hampir dalam tiap kegiatan pengawasan dianggap sebelah mata oleh kabupaten/kota karena provinsi tidak memiliki kewenangan kuat yang tertuang secara jelas dalam PP No. 40 Tahun 2019 (Tabel 1, poin 5 dan 9). Disdukcapil kabupaten/kota salah tafsir terkait fungsi pengawasan dalam era otonomi daerah, mereka menyatakan kewenangan provinsi hanya sebatas koordinasi dan hanya inspektorat yang berwenang melakukan pembinaan, supervisi maupun pengawasan. Hal ini relevan menurut (Azhar, 2012), konflik yang timbul antara pemerintah kab/kota dan provinsi lebih disebabkan kepada tidak jelasnya batas otoritas yang menjadi tanggung jawab serta harus dikontrol oleh masing-masing pemerintah daerah dan oknum pejabat daerah yang memanfaatkan kekuasaannya.

Kondisi seperti ini sekaligus menunjukkan minimnya koordinasi antar tingkatan pemerintahan sebagai satu kesatuan integral yang seharusnya menjalankan fungsinya sebagai pengarah/fasilitator dan yang diarahkan/pihak yang difasilitasi. Padahal, dalam UU 23/2014 walaupun pemda provinsi dan pemda kabupaten/kota bukan merupakan "garis atasan-bawahan" tetapi provinsi memiliki fungsi supervisi, koordinasi dan fasilitasi terhadap kabupaten/kota (Kristiyanto, 2012; Rauf, 2018a). Sejalan dengan hal tersebut, 
Nakhoda: Jurnal Ilmu Pemerintahan

Vol. 19 No. 2 Tahun 2020 Halaman 128-150

e-ISSN: 2656-5277 | p-ISSN: 1829-5827

(Robuwan et al., 2018) mengungkapkan kepala daerah di Indonesia bertanggungjawab secara langsung kepada otoritas yang menyupervisinya atau pengawasan Hybrid, sehingga pemerintah harus melakukan pengawasan berjenjang dimulai dari presiden mengawasi kementerian dan kepala/lembaga non kementerian, kementerian dan kepala/lembaga non kementerian mengawasi pemerintah daerah provinsi dan pemerintah daerah provinsi mengawasi pemerintah daerah kabupaten/kota.

Senada dengan hal itu (Said, 2015) mengungkapkan pemerintah pusat terus melakukan pengawasan terhadap pemerintah daerah agar tidak terjadi penyalahgunaan kewenangan yang diberikan dan sebagai pengikat Negara Kesatuan Republik Indonesia. Berdasarkan uraian di atas maka disdukcapil provinsi berhak melakukan pengawasan administrasi kependudukan dengan tetap memperhatikan norma, standar, prosedur dan kriteria (NPSK) yang berlaku dan disdukcapil kabupaten/kota pun wajib mematuhi provinsi sebagai perwakilan pemerintah pusat di daerah.

Terkait isu kriteria pembagian urusan adalah tidak sesuainya kriteria pembagian urusan di lapangan (Hananto, 2011). Pembagian urusan pemerintahan sesungguhnya telah ditetapkan dengan kriteria: akuntabilitas, efisiensi, eksternalitas, dan kepentingan strategis nasional sesuai Undang-Undang Nomor 23 Tahun 2014 Tentang Pemerintahan Daerah. Hal ini diperkuat (I. M. D. C. A. Sari, 2015) bahwa pembagian kewenangan wajib memenuhi unsur utama :

1) Kriteria eksternalitas; urusan pemerintahan menyesuaikan skala yang terjadi apabila luas maka kewenangan nasional, skala regional maka kewenangan provinsi, dan skala lokal menjadi kewenangan kabupaten/kota.

2) Kriteria akuntabilitas; akan lebih akuntabel jika menyerahkan kewenangan kepada tingkat pemerintahan yang terdampak langsung dari suatu kebijakan.

3) Kriteria efisiensi; akan lebih efisiensi jika menyerahkan kewenangan kepada tingkat pemerintahan yang tersedia sumber dayanya (peralatan, dana, dan personil).

Sehingga apabila disandingkan hasil penelitian di atas dengan fakta di lapangan lebih tepat jika pengadaan blangko dokumen kependudukan dilimpahkan kepada disdukcapil provinsi atau kabupaten/kota untuk mengurangi beban tugas Ditjen Dukcapil dalam melakukan pembinaan, pembimbingan, supervisi, pemantauan, evaluasi, pengawasan dan konsultasi kepada seluruh jajaran disdukcapil diwilayah Indonesia. Pengadaan blangko dokumen kependudukan oleh pemda juga akan sangat mengurangi beban tugas disdukcapil kab/kota dalam memberikan pelayanan secara aktif kepada masyarakat. Kewenangan pusat mengatur provinsi dan kabupaten/kota yang terlihat dalam peraturan-perundangan sudah cukup ketat sehingga bila pengadaan blangko e-KTP diserahkan kepada provinsi/kabupaten/kota akan melonggarkan resistensi daerah itu sendiri. Kementerian cukup menunjuk penyedia yang kompeten dalam e-katalog nasional. Dengan e-katalog nasional dan pengaturan pembelian blangko diharapkan pelayanan disdukcapil menjadi lebih transparan, efisien dan meningkatkan efektivitas penyelenggaraan pemerintah daerah. Tugas pemerintah dapat terlaksana dengan baik bila terjadi pembagian kewenangan yang tepat dan jelas sesuai dengan maksud dan tujuannya (Rokhim, 2013).

Keengganan kementerian sektoral untuk menyerahkan kewenangan dan mendistribusikan anggaran yang dimiliki melalui mekanisme Dana Alokasi Khusus (DAK) non fisik disebabkan kementerian sektoral akan kehilangan kewenangannya dalam mengelola anggaran tersebut (Fatmawati, 2018). Akhirnya, untuk menghindari terjadinya kehilangan kewenangan dan tetap ikut serta dalam pengelolaan anggaran, kementerian mendistribusikan kewenangan yang tidak memiliki pengaruh besar. Padahal menurut (Ekwarso \& Sari, 2010) administrasi kependudukan bukan hanya urusan surat menyurat 
Nakhoda: Jurnal Ilmu Pemerintahan

Vol. 19 No. 2 Tahun 2020 Halaman 128-150

e-ISSN: 2656-5277 | p-ISSN: 1829-5827

tetapi merupakan bagian dari manajemen kependudukan, di mana proses perencanaan, pengelolaan, pengorganisasi dan pengawasan penduduk saling berkesinambungan. Pelayanan administrasi kependudukan dapat kita amati dari tabel 6 Laporan Perkembangan KTP-el, Akta Kelahiran, dan Akta Kematian pada Bulan Februari 2020 yang disajikan pada Tabel 6.

Tabel 6. Laporan Perkembangan KTP el, Akta Kelahiran, \& Akta Kematian Februari 2020

\begin{tabular}{|c|c|c|c|c|c|c|c|}
\hline No. & $\begin{array}{c}\text { Kabupaten } \\
\text { / Kota }\end{array}$ & Wajib KTP & Rekam & Cetak & $\begin{array}{l}\text { PRR (print } \\
\text { ready } \\
\text { record }^{*} \text { ) }\end{array}$ & $\begin{array}{c}\% \\
\text { Kepemilik } \\
\text { an akta } \\
\text { kelahiran }\end{array}$ & $\begin{array}{c}\% \\
\text { Kepemili } \\
\text { kan akta } \\
\text { kematian }\end{array}$ \\
\hline 1 & $\begin{array}{l}\text { Kotawaringin } \\
\text { Barat }\end{array}$ & 181.844 & 187.907 & 184.325 & 2.379 & 85,15 & 100,0 \\
\hline 2 & $\begin{array}{l}\text { Kotawaringin } \\
\text { Timur }\end{array}$ & 292.729 & 272.517 & 308.333 & 7.766 & 60,21 & 100,0 \\
\hline 3 & Kapuas & 301.553 & 256.773 & 313.627 & 898 & 91,71 & 91,9 \\
\hline 4 & Barito Selatan & 93.994 & 97.765 & 97.107 & 658 & 93,30 & 84,4 \\
\hline 5 & Barito Utara & 111.261 & 103.908 & 103.820 & 13 & 95,28 & 96,4 \\
\hline 6 & Katingan & 107.430 & 105.015 & 105.010 & 5 & 93,54 & 100,0 \\
\hline 7 & Seruyan & 102.233 & 95.821 & 94.936 & 826 & 85,96 & 100,0 \\
\hline 8 & Sukamara & 43.097 & 44.100 & 43.909 & 191 & 86,64 & 24,9 \\
\hline 9 & Lamandau & 67.769 & 66.124 & 65.897 & 227 & 47,53 & 100,0 \\
\hline 10 & Gunung Mas & 92.702 & 74.056 & 73.701 & 355 & 76,27 & 100,0 \\
\hline 11 & Pulang Pisau & 93.505 & 88.970 & 84.943 & 570 & 78,16 & 94,7 \\
\hline 12 & Murung Raya & 72.508 & 71.820 & 67.268 & 2.085 & 73,62 & 6,6 \\
\hline 13 & Barito Timur & 83.008 & 78.985 & 81.580 & 3.255 & 98,57 & 100,0 \\
\hline \multirow[t]{2}{*}{14} & Palangka raya & 192.554 & 192.112 & 193.273 & 5.743 & 96,72 & 100,0 \\
\hline & $\begin{array}{l}\text { Total Prov. } \\
\text { Kalteng }\end{array}$ & 1.836 .187 & 1.735 .873 & 1.817 .729 & 24.971 & 77,25 & 86,1 \\
\hline
\end{tabular}

Keterangan : *Data siap cetak menunggu ketersediaan blangko KTP-el dari kementerian Sumber : Dokumen Laporan Data Kependudukan. Data diolah. (2020)

Berdasarkan Laporan (Seksi Penyajian Data, 2020), dengan jumlah wajib KTP Semester I Prov. Kalteng mencapai 1.836.187 jiwa, yang telah melakukan perekaman KTPel namun belum tercetak KTP-nya karena keterbatasan blangko berjumlah 24.971 jiwa, jumlah penduduk yang belum memiliki akta kelahiran 257.050 jiwa atau 77,25\% dan jumlah penduduk yang belum memiliki akta kematian 4.336 jiwa atau $86,1 \%$. Masih jauh dari standar nasional yang ingin dicapai apabila kewenangan pengadaan blangko masih menjadi milik pusat. Pelayanan administrasi kependudukan bagi masyarakat Provinsi Kalimantan Tengah tidak bertambah baik dapat dilihat dari rendahnya rata-rata capaian KTP-el di bawah standar nasional 98,78\%, akta kelahiran di bawah standar nasional 85\% dan akta kematian di bawah standar nasional $90 \%$.

Sudah menjadi rahasia umum bahwa kementerian menahan menyerahkan wewenang administrasi kependudukan kepada daerah (Mujahidin \& Wiredarme, 2020). Tentu wajar jika dilakukan dengan benar dan sesuai dengan kepentingan yang lebih besar. Kriteria "kepentingan strategis nasional" mungkin dapat menjadi alat pembenar dilakukannya pembagian urusan. Namun, apabila pembagian tersebut dilakukan secara sewenang-wenang tentu akan berakibat kontra produktif dalam penyelenggaraan urusan administrasi kependudukan (Fatmawati, 2018). Dalam spektrum yang lebih luas, hambatanhambatan di atas dapat terjadi pada berbagai urusan, bukan hanya pada urusan administrasi 
Nakhoda: Jurnal Ilmu Pemerintahan

Vol. 19 No. 2 Tahun 2020 Halaman 128-150

e-ISSN: 2656-5277 | p-ISSN: 1829-5827

kependudukan di Kalimantan Tengah, tetapi juga pada urusan kesehatan, pekerjaan umum dan pendidikan di seluruh wilayah Indonesia. Para pemangku kepentingan penyelenggara administrasi kependudukan baik di pusat, provinsi, maupun kabupaten/kota harus sering duduk bersama menjalin komunikasi dan koordinasi sampai terciptanya interkoneksi dan interdependensi program dan kegiatan (Akbal, 2016; Halik, 2015; PKP2A III LAN, 2007). Kesatuan sistem pemerintahan ini diperlukan karena pusat memiliki wilayah kerja yang luas di daerah dan daerah itu memiliki pemerintah pusat.

\section{Kesimpulan}

Pelaksanaan PP No. 40 Tahun 2019 menimbulkan hambatan dalam hubungan kewenangan, kelembagaan, keuangan, dan pengawasan antara pemerintah pusat dan daerah, antara lain pertama, hambatan distorsi dalam pelaksanaan asas penyelenggaraan pemerintahan daerah. Terjadinya benturan regulasi di mana posisi kementerian sebagai pemegang kewenangan tertinggi cenderung berfokus pada kepentingan pusat tanpa mengakomodir potensi atau keterbatasan suatu daerah. Penyeragaman seluruh peraturan perundang-undangan tentang administrasi kependudukan dan pencatatan sipil bertujuan agar semua daerah dapat mudah dikelola dan diatur dengan cara yang sama. Kemudian komposisi anggaran DAK non fisik yang tidak berimbang dari APDB menyebabkan daerah kesulitan untuk melaksanakan berbagai kewenangan yang dilimpahkan. Sehingga disimpulkan problematika kewenangan administrasi kependudukan yang pertama adalah pengaturan kementerian yang berlebihan sehingga tidak mengakomodir ruang bagi tindakan diskresi aparatur sipil negara dalam mengatasi permasalahan pelayanan administrasi kependudukan di daerah.

Kemudian kedua, hambatan distribusi urusan administrasi kependudukan dan kriteria pembagian urusan. Di mana kementerian sering menuntut pemerintah daerah untuk melaksanakan tugas yang tidak tertuang dalam PP 40/2019 dan terus mengerjakan urusan yang telah di distribusikan ke daerah. Pendistribusian fungi pengawasan dan koordinasi yang lemah juga menyebabkan konflik antara provinsi dan kabupaten/kota karena PP 40/2019 tidak menjelaskannya secara utuh. Dalam kriteria pembagian urusan telah ditetapkan sesuai kriteria utama akuntabilitas, efisiensi, eksternalitas, dan kepentingan strategis nasional. Tetapi dengan alasan menjaga kepentingan strategis nasional, kementerian sengaja menahan menyerahkan wewenang pentingnya kepada pemerintah daerah. Sehingga disimpulkan problematika kewenangan administrasi kependudukan yang kedua adalah ketidakadilan pembagian kewenangan administrasi kependudukan di pemerintah daerah. Dalam konteks pemberlakuan PP No. 40 Tahun 2019, upaya untuk menelisik kemungkinan munculnya permasalahan-permasalahan turunannya masih tetap relevan dan layak menjadi perhatian semua pihak guna menyusun antisipasi penanggulangannya. Untuk itu rekomendasi yang disampaikan penulis antara lain :

1. Menghadapi permasalahan distorsi asas penyelenggaraan pemerintahan daerah di mana benturan regulasi dan kerancuan penerapan asas dekonsentrasi/tugas pembantuan terjadi. Langkah yang perlu ditempuh oleh pusat/kementerian seyogianya merangkul daerah, berkolaborasi untuk berbagi beban seperti menerima masukan disdukcapil tentang fakta pekerjaan dan bersedia merealokasi DAK non fisik dan APBD guna peningkatan kinerja pelayanan administrasi kependudukan. Pemerintah kabupaten/kota juga harus kooperatif kepada pemerintah provinsi/kementerian. Bukankah pusat itu pusat kerjanya di daerah dan daerah itu wilayahnya pusat? Melakukan sinergi dengan menjalin komunikasi dan koordinasi yang baik merupakan salah satu cara memutuskan resistensi berlebih dari daerah atas kebijakan pusat. 
Nakhoda: Jurnal IImu Pemerintahan

Vol. 19 No. 2 Tahun 2020 Halaman 128-150

e-ISSN: 2656-5277 | p-ISSN: 1829-5827

2. Menghadapi permasalahan distribusi urusan administrasi kependudukan dan kriteria pembagian urusan di mana kementerian mengerjakan tugas yang sama dengan tugas daerah, lemahnya pengawasan administrasi kependudukan oleh provinsi dan tidak sesuainya kriteria pembagian urusan di lapangan. Langkah yang perlu ditempuh dengan merevisi UU No. 23/2014, sekiranya pusat dapat membentuk local selfgovernment dan menyerahkan urusan pemerintahan khususnya yang berhubungan dengan dekonsentrasi dan tugas pembantuan. Pusat dapat mengangkat pejabat dekonsentrasi/tugas pembantuan (komisaris) di provinsi, kab/kota dan desa dengan diberikan kewenangan perwakilan. Pusat menetapkan mendagri sebagai komandan dan mendagri memberi perintah kepada komisaris provinsi, kab/kota dan desa untuk melaksanakan kebijakan pusat. Komisaris provinsi, kab/kota, dan desa sebagai komandan dekonsentrasi/tugas pembantuan pada daerahnya masing-masing. Kepala daerah provinsi, kabupaten/kota, dan desa bertanggung jawab kepada komisaris masing-masing kemudian komisaris desa bertanggung jawab kepada komisaris kab/kota, komisaris kab/kota bertanggung jawab kepada komisaris provinsi, komisaris provinsi bertanggung jawab kepada mendagri, dan mendagri bertanggung jawab kepada presiden. Dengan model ini diharapkan pemerintah pusat memiliki kendali penuh terhadap kegiatan dekonsentrasi dan tugas pembantuan di daerah, sehingga pembagian urusan di lapangan menjadi adil, tumpang tindih urusan dan lemahnya pengawasan tidak akan terjadi lagi.

\section{Daftar Pustaka}

Akbal, M. (2016). Harmonisasi Kewenangan Antara Pemerintah Pusat Dan Daerah Dalam Penyelenggaraan Otonomi Daerah. Jurnal Supremasi, XI(2), 99-107. http://103.76.50.195/supremasi/article/view/2800/1505

Albintani, M. (2018). Quo vadis MPR RI: antara eksistensi dan legalitas produk? Nakhoda: Jurnal Ilmu Pemerintahan, 14(24), 1-7. https://doi.org/https://doi.org/10.35967/jipn

Albintani, M., \& Marta, A. (2020). Provinsi "Istimewa Melayu Kepulauan Riau"(Gagasan Permulaan). Nakhoda: Jurnal Ilmu Pemerintahan, 19(1), 56-74. https://doi.org/https://doi.org/10.35967/jipn

Azhar, M. A. (2012). Desentralisasi dan Konflik Kewenangan (Studi Konflik Kewenagan antara Pemerintah Provinisi Sulawesi Tenggara dengan Pemerintah Kota Kendari dalam Kasus Perizinan Investasi PT. Artha Graha rup). Jurnal Administrasi Negara, III(1), 62-75.

Bansaleng, E. B. C. (2017). Kewenangan Pemerintah Daerah Dalam Penyelenggaraan Pelayanan Publik Menurut Undang-Undang Nomor 25 Tahun 2009. Lex Administratum, 5 No.2(1), 20-28.

Dwiyanto, A. (2011). Pembagian urusan pemerintahan: problema dan rekomendasi kebijakan. The World Bank.

Ekwarso, H., \& Sari, L. (2010). Penyerasian Kebijakan Kependudukan di Provinsi Riau. Jurnal Ekonomi Universitas Riau, 18(2), 36-419. http://download.portalgaruda.org/article.php?article=31436\&val=2268

Fatmawati, N. I. (2018). Desentralisasi Asimetris, Alternatif Bagi Masa Depan Pembagian Kewenangan di Indonesia. Madani Jurnal Politik Dan Sosial, 10(3), 73-85.

Febrianda, L. (2009). Rekonstruksi Regulasi Pelayanan Kependudukan dan Pencatatan Sipil oleh Birokrasi Pemerintahan Dalam Perspektif Hukum Administrasi Negara [Universitas Diponegoro Semarang]. http://eprints.undip.ac.id/24631/

Halik, A. (2015). Implementasi Kebijakan Pelimpahan Urusan Pemerintahan Lingkup Kementerian Dalam Negeri. Jurnal Bina Praja, 07(02), 131-148. 
Nakhoda: Jurnal Ilmu Pemerintahan

Vol. 19 No. 2 Tahun 2020 Halaman 128-150

e-ISSN: 2656-5277 | p-ISSN: 1829-5827

https://doi.org/10.21787/jbp.07.2015.131-148

Hananto, U. D. (2011). Asas Desentralisasi dan Tugas Pembantuan dalam UU No. 32

Tahun 2004 tentang Pemerintahan Daerah. Masalah-Masalah Hukum, 40(2), 202-212. https://ejournal.undip.ac.id/index.php/mmh/article/viewFile/10471/8347https://accoun ts.google.com/ServiceLogin/signinchooser?continue=https $\% 3 \mathrm{~A} \% 2 \mathrm{~F} \% 2 \mathrm{Fmail}$.google.c om $\% 2$ Fmail $\% 2 F \&$ osid= $=1 \&$ service=mail $\& s s=1 \& l \mathrm{tmpl}=$ default $\& \mathrm{rm}=$ false $\&$ flow $N a m e$ $=$ GlifWebSignIn\&flowEntry=

Indah. (2014). Hubungan Wewenang Antara Pemerintah Pusat Dan Daerah Dalam Negara Kesatuan Republik Indonesia. Rechtidee Jurnal Hukum Fakultas Hukum Universitas Brawijaya, $\quad 9 \quad$ No.2(December), 136-153. https://journal.trunojoyo.ac.id/rechtidee/article/download/405/378

Ismail, N. (2019). Kewenangan Dekonsentrasi Kepala Daerah Dalam Penyelenggaraan Pengelolaan Keuangan Daerah. Gorontalo Law Review, 2(1), 24-32.

Kebijakan Pengadaan Barang/Jasa Pemerintah, L. (2020). Hibah barang dan jasa yang akan diserahkan kepada pihak ketiga. Sirup.Lkpp.Go.Id. https://sirup.lkpp.go.id/sirup/ro/cari?tahunAnggaran=2019\&keyword=dinas+kependu dukan+dan+catatan+sipil+provinsi+kalimantan+tengah\&jenisPengadaan=1\&metodeP engadaan $=14$

Kristiyanto, E. N. (2012). Pemilihan Gubernur Tak Langsung Sebagai Penegasan Eksistensi Gubernur Sebagai Wakil Pemerintah Pusat Di Daerah. Jurnal Rechts Vinding: Media Pembinaan Hukum Nasional, 1(3), 397-408. https://doi.org/10.33331/rechtsvinding.v1i3.92

Lubis, B., \& Mulyaningsih, S. (2016). Implementasi Perekaman E-KTP Di Kabupaten Cianjur Provinsi Jawa Barat (Studi Kasus Di Kecamatan Ciranjang). Jurnal Ilmiah Wahana Bhakti Praja, 6(1), 25-34. https://doi.org/10.33701/jiwbp.v6i1.132

Mujahidin, M., \& Wiredarme, W. (2020). Desentralisasi Kewenangan Bidang Administrasi Kependudukan Dan Pencatatan Sipil. Jatiswara, 35(1), 72-77. https://doi.org/10.29303/jatiswara.v34i1.232

Nugraha, I. P. B. I. M., \& Dwirandra, A. A. N. B. (2016). Kemampuan Pertumbuhan Ekonomi Memoderasi Pengaruh Pajak Daerah, Retribusi Daerah, DAU Dan DBH Pada Belanja Modal. E-Jurnal Akuntansi Universitas Udayana, 14(1), 284-311.

Nur Wijayanti, S. (2016). Hubungan Antara Pusat dan Daerah Dalam Negara Kesatuan Republik Indonesia Berdasarkan Undang-Undang Nomor 23 Tahun 2014. Jurnal Media Hukum, 23(2), 186-199. https://doi.org/10.18196/jmh.2016.0079.186-199

Pamungkas, L. D., \& Fitriati, R. (2019). Best Practice Pelayanan Administrasi Kependudukan Kabupaten Kudus. Dialogue: Jurnal Ilmu Administrasi Publik, 1(2), 26-39. https://doi.org/10.14710/dialogue.v1i2.6611

Patawari, P. (2012). Perspektif Hukum Refleksif Terhadap Hubungan Kewenangan Antar Pemerintahan Pusat Dan Daerah. Jurnal Ilmu Hukum AMANNA GAPPA, 20(2), 180 193. https://doi.org/10.31219/osf.io/kt96q

PKP2A III LAN, T. (2007). Kewenangan Dekonsentrasi Dalam Penyelenggaraan Otonomi Daerah Dan Permasalahan Penyelenggaraanya Di Daerah. Jurnal Borneo Administrator, 4(1), 1-22. https://doi.org/10.24258/jba.v4i1.23

Pratama, K. (2013). Analisis Kinerja Dinas Kependudukan Dan Pencatatan Sipil Kota Palu Dalam Penerapan Kartu Tanda Penduduk Elektronik Di Kota Palu. Katalogis, 1(7), 147-153.

Prihatiningsih, A., R., M. R., \& HM, S. (2013). Defisit Anggaran dan Implikasinya terhadap Perkembangan Ekonomi dan Kinerja Keuangan Kabupaten Tebo. Jurnal Perspektif Pembiayaan Dan Pembangunan Daerah Program Magister Ilmu Ekonomi Fak. Ekonomi Universitas Jambi, 1(2), 97-108. 
Nakhoda: Jurnal Ilmu Pemerintahan

Vol. 19 No. 2 Tahun 2020 Halaman 128-150

e-ISSN: 2656-5277 | p-ISSN: 1829-5827

Rauf, R. (2018a). Eksistensi Gubernur Sebagai Wakil Pemerintah Pusat Di Daerah. Jurnal Kajian Pemerintah, IV(1), 1-55.

Rauf, R. (2018b). Perkembangan Asas Tugas Pembantuan. Jurnal Wedana, IV(1), 460 469.

Ridwan, H. R. (2003). Hukum Administrasi Negara, Cetakan Kedua. UII Press, Yogyakarta.

Ridwan, J., \& Sodik, A. (2012). Hukum Administrasi Negara dan Kebijakan Pelayanan Publik. Nuansa Cendekia.

Rina Wahyuni. (2015). Perancangan Knowledge Management System: Studi Kasus Koordinator Wilayah Direktorat Jenderal Kependudukan Dan Pencatatan Sipil Kementerian Dalam Negeri [Universitas Indonesia Jakarta]. http://lib.ui.ac.id/file?file=digital/2016-5/20405146-TA-Rina Wahyuni.pdf

Ripa'i, A. (2018). Penerapan Sistem Informasi Administrasi kependudukan Berbasis Teknologi Informasi Menuju Single Identity Number Di Dinas Kependudukan Dan Pencatatan Sipil Kabupaten Sumedang Provinsi Jawa Barat. Jurnal Dukcapil, 6(1), 67-85.

Robuwan, R., Wirazilmustaan, \& Agustian, R. A. (2018). Konsep Hubungan Kewenangan Antara Pemerintah Pusat Dan Pemerintah Daerah Dalam Bingkai Negara Kesatuan Dengan Corak Otonomi Luas. PROGRESIF: Jurnal Hukum, 12(2), 2131-2145. https://doi.org/10.33019/progresif.v12i2.976

Rokhim, A. (2013). Kewenangan Pemerintahan Dalam Konteks Negara Kesejahteraan (Welfare State). Jurnal Ilmiah Dinamika Hukum, XIX(36), 136-148.

Romli, L. (2007). Potret Otonomi Daerah dan Wakil Rakyat di Tingkat Lokal. Pustaka Pelajar.

Said, A. R. A. (2015). Pembagian Kewenangan Pemerintah Pusat - Pemerintah Daerah Dalam Otonomi Seluas - luasnya Menurut UUD 1945. Fiat Justisia Jurnal Ilmu Hukum, 9(4), $505-530$. http://jurnal.fh.unila.ac.id/index.php/fiat/article/viewFile/613/552

Sari, E. T. I., \& Asyik, N. F. (2017). Pengaruh PAD, DAU, DAK Dan DBH Terhadap Belanja Daerah ( Studi Pada Pemerintah Daerah Kabupaten / Kota di Provinsi Jawa Timur). Jurnal Ilmu Dan Riset Akuntansi, 6(5), 1977-1994.

Sari, I. M. D. C. A. (2015). Kewenangan Pemerintah Pusat Dengan Pemerintah Daerah Dalam Pelaksanaan Kegiatan Alokasi Dana Cukai Hasil Tembakau. Yuridika, 28(2), 217-242. https://doi.org/10.20473/ydk.v28i2.1882

Sasana, H. (2011). Analisis Determinan Belanja Daerah Di Kabupaten/Kota Provinsi Jawa Barat Dalam Era Otonomi Dan Desentralisasi Fiskal (Analysis Determinants in Regional Shopping District/City West Java Province In Era Autonomy and Fiscal Decentralization). Jurnal Bisnis Dan Ekonomi (JBE), 18(1), 46-58.

Seksi Penyajian Data. (2020). Laporan Perkembangan KTP-el, Akta Kelahiran Dan Akta Kematian Bagi Penduduk Usia 0-18 Tahun Bulan Februari dan November Tahun 2020.

Setiaji, W., \& Adi, P. H. (2007). Peta Kemampuan Keuangan Daerah Sesudah Otonomi Daerah: Apakah Mengalami Pergeseran? (Studi pada Kabupaten dan Kota Se-Jawa Bali). Simposium Nasional Akuntansi X, June, 1-29.

Setiawan, H., \& Ikhsanditya, F. (2020). Gerakan Masyarakat Tertib Administrasi Kependudukan Melalui Inovasi Pelayanan Lukadesi (Keluarga Berduka Desa Siaga) di Kabupaten Sleman D.I. Yogyakarta. Nakhoda: Jurnal Ilmu Pemerintahan, 19(1), 38-55. https://doi.org/https://doi.org/10.35967/jipn

Simandjuntak, R. (2016). Sistem Desentralisasi Dalam Negara Kesatuan Republik Indonesia Perspektif Yuridis Konstitusional. Journal de Jure, Jurnal Syariah Dan 
Nakhoda: Jurnal Ilmu Pemerintahan

Vol. 19 No. 2 Tahun 2020 Halaman 128-150

e-ISSN: 2656-5277 | p-ISSN: 1829-5827

Hukum, 7(1), 57-67. https://doi.org/10.18860/j-fsh.v7i1.3512

Snyder, H. (2019). Literature review as a research methodology: An overview and guidelines. Journal of Business Research, 104, 333-339. https://doi.org/https://dx.doi.org/10.1016/j.jbusres.2019.07.039

Soemarsono, M. (2017). Negara Hukum Indonesia Ditinjau Dari Sudut Teori Tujuan Negara. Jurnal Hukum \& Pembangunan, 37(2), 300-322. https://doi.org/10.21143/jhp.vol37.no2.1480

Soemartono, T., \& Hendrastuti, S. (2011). Administrasi kependudukan berbasis registrasi. Yayasan Bina Profesi Mandiri.

Strong, C. F. (2011). Konstitusi-Konstitusi Politik Modern. Terjemahan, Nusa Media, Bandung.

Sukma, H. N., Amrina, E., \& Hasan, A. (2018). Evaluasi Proses Pelayanan Administrasi Kependudukan dengan Metode Lean Office. Jurnal Optimasi Sistem Industri, 17(2), 171-187. https://doi.org/10.25077/josi.v17.n2.p171-187.2018

Sutarto, S. (2000). Dasar-Dasar Organisasi. Gadjah Mada University Press, Yogyakarta.

Thoha, M. (2003). Birokrasi dan politik di Indonesia. Divisi Buku Perguruan Tinggi, RajaGrafindo Persada.

Thoha, M. (2004). Perilaku Organisasi: Konsep Dasar dan Aplikasinya: Jakarta.

Wasistiono, S. (2003). Kapita Selekta Penyelenggaraan Pemerintah Daerah. Bandung: Fokusmedia.

Wicaksono, K. (2012). Problematika dan Tantangan Desentralisasi di Indonesia. Jurnal Bina Praja, 4(1), 21-28. https://doi.org/10.21787/jbp.04.2012.21-28

Yusdianto, Y. (2015). Hubungan Kewenangan Pusat dan Daerah Menurut Undang-Undang Nomor 23 Tahun 2014 tentang Pemerintahan Daerah. PADJADJARAN Jurnal Ilmu Hukum (Journal of Law), 2(3), 483-504. https://doi.org/10.22304/pjih.v2n3.a4 